\title{
Stability Control Mechanism of High-Stress Roadway Surrounding Rock by Roof Fracturing and Rock Mass Filling
}

\author{
Fuzhou Qi $\mathbb{D}^{1},{ }^{1}$ Zhanguo $\mathrm{Ma}^{2}$ Dangwei Yang, ${ }^{3}$ Ning Li $\mathbb{D}^{2}{ }^{2}$ Bin Li, ${ }^{1}$ Zhiliu Wang, \\ and Weixia $\mathrm{Ma}^{4}$ \\ ${ }^{1}$ School of Civil \& Architecture Engineering, Zhongyuan University of Technology, Zhengzhou 450007, Henan, China \\ ${ }^{2}$ State Key Laboratory for Geomechanics and Deep Underground Engineering, China University of Mining and Technology, \\ Xuzhou 221116, China \\ ${ }^{3}$ Pingdingshan Coal No. 10 mine, Pingdingshan 467000, China \\ ${ }^{4}$ Earthquake Administration of Henan, Zhengzhou 450016, Henan, China
}

Correspondence should be addressed to Fuzhou Qi; 18255416386@163.com

Received 21 December 2020; Revised 17 January 2021; Accepted 19 February 2021; Published 1 March 2021

Academic Editor: Hualei Zhang

Copyright (C) 2021 Fuzhou Qi et al. This is an open access article distributed under the Creative Commons Attribution License, which permits unrestricted use, distribution, and reproduction in any medium, provided the original work is properly cited.

\begin{abstract}
Large deformation of roadway and coal bump failures have always been the focus in deep underground engineering. By considering the Lu'an mining district in China, the failure mode and stability improvement process of high-stress roadways were analysed with the field tests and numerical simulations. The field test results showed that a great amount of deformation and serious damage occurred in surrounding rocks during panel retreat due to the suspended roof. A novel approach employing roof fracturing and collapsed rock filling effect was adopted to maintain the roadway stability. A numerical model was established with the Universal Distinct Element Code (UDEC) to research the fracturing characteristics between the roadway and gob roofs and the stress change in the surrounding rock. The modelling results demonstrated that, without fracturing roof, the peak vertical stress of the coal pillar was 18.3 MPa and the peak vertical stress of the virgin coal rib was 15.6 MPa. The roadway was in a state of high stress. With fracturing roof, the peak vertical stress of coal pillar was $9.3 \mathrm{MPa}$ and the peak vertical stress of virgin coal rib was 13.4 MPa. The fractured rock mass in the gob expanded in volume and provided supporting resistance to the overlying strata, which relieved stress concentrations in the coal pillar. Field measurement results indicated that the roadway large deformation was successfully resolved during excavation and panel retreat after implementing the novel approach, providing useful references for the application of this novel approach in similar coal mines.
\end{abstract}

\section{Introduction}

With increases in mining depth, the instability of high-stress roadways has become a major challenge for deep underground coal mines [1, 2]. In high-stress environments, roadways exhibit serious damage such as roof sags, coal rib bulging, and coal bumps caused by massive suspended roofs. All these outcomes may lead to casualties and production losses, which affect roadway function. Therefore, research on the failure process and control mechanisms of high-stress roadways has become essential to provide workers with a safe environment. Many means have been selected to analyse the deformation, stress laws, and stability of roadways, including theoretical analysis [3, 4], field tests [5-7], model tests $[8,9]$, and numerical simulations.

In reality, many factors, such as the mechanical behaviour of the surrounding rock, in situ stress, and mining sequence, should be considered in theoretical analyses. Because the above factors are not included in theoretical analyses, such analyses are limited in application. Model tests are common methods used to simulate roadway failure processes. Liu et al. [10] adopted model testing to research the roadway stress distribution in bedding rock masses with asymmetrical loading. Based on an analysis of infrared and displacement field images, Sun et al. [11] investigated the deformation failure mechanism of surrounding rocks during 
roadway excavations by physical model tests. However, the application of model tests is also not widely used because the real stress states of surrounding rock cannot be simulated in physical modelling tests, and the test setup is complex.

In recent years, due to high efficiency and low cost, a large number of numerical simulations have been used to investigate roadway stability. John Coggan et al. [12] analysed the effects of horizontal stress and weak immediate roof lithology on roadway roof stability. Kang et al. [13] investigated the influences of thermal, hydraulic, and mechanical fields on a high-stress roadway in a deep coal mine, considering the water-weakening effect of the surrounding rock. Shen [14] simulated the failure mechanism of a deep soft rock roadway with UDEC software and found that the high stress and low strength of surrounding rock were the main causes of roadway instability. Gao et al. [15] applied UDEC to simulate the squeezing failure behaviour of roadway roofs due to mining-induced stress and described the discontinuous damage process. Wang et al. [16] undertook research on the dynamic response and failure mechanisms of a roadway during the mining process; their results showed that the high stress of a coal pillar was the main factor leading to coal bumps. Zhang et al. [17] adopted an interface model to investigate the influence of defect location and thickness on the surrounding rock stability.

Previous studies have often focused on factors influencing the stress distributions of roadways, including burial depth, geological conditions, rock mass characteristics, and mining-induced effects. However, based on roof fracturing and rock mass filling, a novel approach has been proposed for adjusting the stress conditions of roadways and improving the stability of rock masses in this study. For the novel approach, the roof strata above the roadway and gob are cut off by roof fracturing, which optimizes the stress environment in the roadway. Through the fractured rock mass volume bulking, a stable rock filling structure is built in the gob to sustain the overlying strata, which further reduces the loads borne by the two ribs of the high-stress roadway.

In this study, the field test and numerical simulation were adopted to research failure law and stability improvement mechanism of high-stress roadways. First, the deformation failure characteristics of deep roadway and the movement of roof strata were analysed. Second, to understand the stability improvement process of high-stress roadways, the fracture properties of roof strata and the stress change laws of roadway surrounding rock were investigated by a numerical model for the case of the Wangzhuang coal mine. Finally, a proposed novel design principle was implemented in a field test to control roadway deformation based on roof fracturing and the broken rock bulking effect. The modelling procedure and design principle adopted in this study are necessary to analyse the stability of high-stress roadways in other similar sites.

\section{Engineering Background}

2.1. Geology Conditions. As shown in Figure 1, the location of the study site is selected in the Lu'an mining district, Shanxi Province, China. The average burial depth and thickness of the coal seam at the study site are $300 \mathrm{~m}$ and $4 \mathrm{~m}$, respectively. Panels 8106,8107 , and 8108 are located in mining area \#8 of the deep coal mine (Figure 2), which has a strike length of $1088 \mathrm{~m}$ and a dip length of $210 \mathrm{~m}$. The 8106 panel is located south of the 8107 panel and has been mined. The 8108 panel is located north of the 8107 panel and has not been mined. The 8107 headgate is excavated along the 8107 panel (Figure 2), and a $10 \mathrm{~m}$ width is adopted for the coal pillar. The roadway roof strata mainly include mudstone $(3.6 \mathrm{~m})$, siltstone $(7.8 \mathrm{~m})$, and sandy mudstone $(6.4 \mathrm{~m})$, and the roadway floor strata mainly include mudstone $(4.2 \mathrm{~m})$, fine sandstone $(6.4 \mathrm{~m})$, and siltstone $(4.5 \mathrm{~m})$. A detailed stratigraphic column is shown in Figure 3.

The section of the 8107 headgate is rectangular, with a width of $5 \mathrm{~m}$ and a height of $3.5 \mathrm{~m}$. Four deformation measurement stations were installed $50 \mathrm{~m}$ from the front of the 8107 headgate (Figure 2). In the process of excavation and panel retreat, deformation of the roof, floor, and two roadway ribs was observed. The pins (blue solid circle in Figure 4(a)) were fixed to the corresponding regions of the roadway at each measurement station. The pins between the roof and floor were installed at the middle position of the roof, and the pins for the coal rib were installed $1.7 \mathrm{~m}$ from the roof. The measurements of the deformation and internal conditions of the rock mass were carried out with a digital measuring instrument (JSS30A-30) and rock layer detection recorder (YTJ20), respectively, as shown in Figure 4(b). The measuring range of the digital deformation instrument is $0.5-30 \mathrm{~m}$, and the accuracy is $0.01 \mathrm{~mm}$. During the displacement observation, a digital deformation instrument was used with the pins fixed in the position of the roadway rock mass. The image of the rock layer detection recorder is accurate to 1.5 million pixels and can identify $0.1 \mathrm{~mm}$ rock cracks. Thus, the rock layer detection recorder can characterize fissures at different rock depths.

Figure 5 shows the convergence of the 8107 headgate during the excavation and panel retreat stages. After the $58^{\text {th }}$ day of excavation, the deformation tended to keep steady, with a rate of deformation close to zero (Figure 5(a)). The total convergences for the roof, coal pillar rib, and virgin coal rib were $263 \mathrm{~mm}$, $197 \mathrm{~mm}$, and $115 \mathrm{~mm}$, respectively. As shown in Figure 5(b), compared with the convergence during roadway excavation, the displacement of the roadway grew rapidly during panel retreat. The convergence of the roadway roof increased to $952 \mathrm{~mm}$ and the coal pillar rib and virgin coal rib convergence reached $718 \mathrm{~mm}$ and $410 \mathrm{~mm}$, respectively. More than $80 \%$ of the roadway deformation occurred in a location before the working face $45 \mathrm{~m}$. Displacement laws show that the deformation of the roof is larger than that of the two ribs in the roadway. The floor heave was considerably smaller than that of the roadway roof and the two ribs. The deformation failure of the 8107 headgate is shown in Figure 6. The immediate roof and two ribs of the 8107 headgate were located in the coal seam with low strength, and the floor was located in mudstone with relatively high strength. This special geological condition and high stress led to considerable deformation of the roof and the two ribs with roadway excavation and panel retreat.

Figure 7 shows photographs obtained by the rock layer detection recorder of the coal pillar at measurement station 


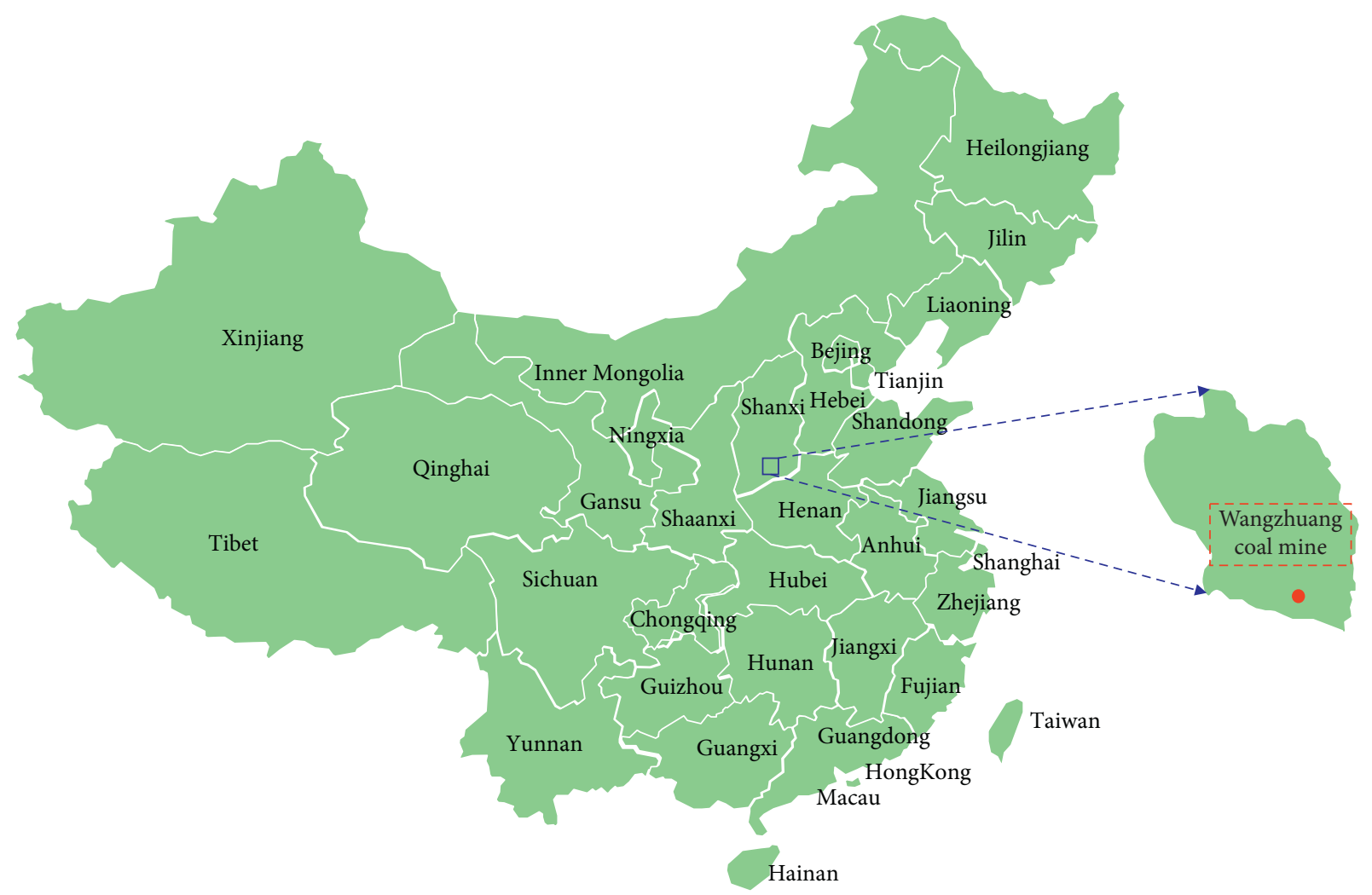

Figure 1: Location of the Lu'an mining district.

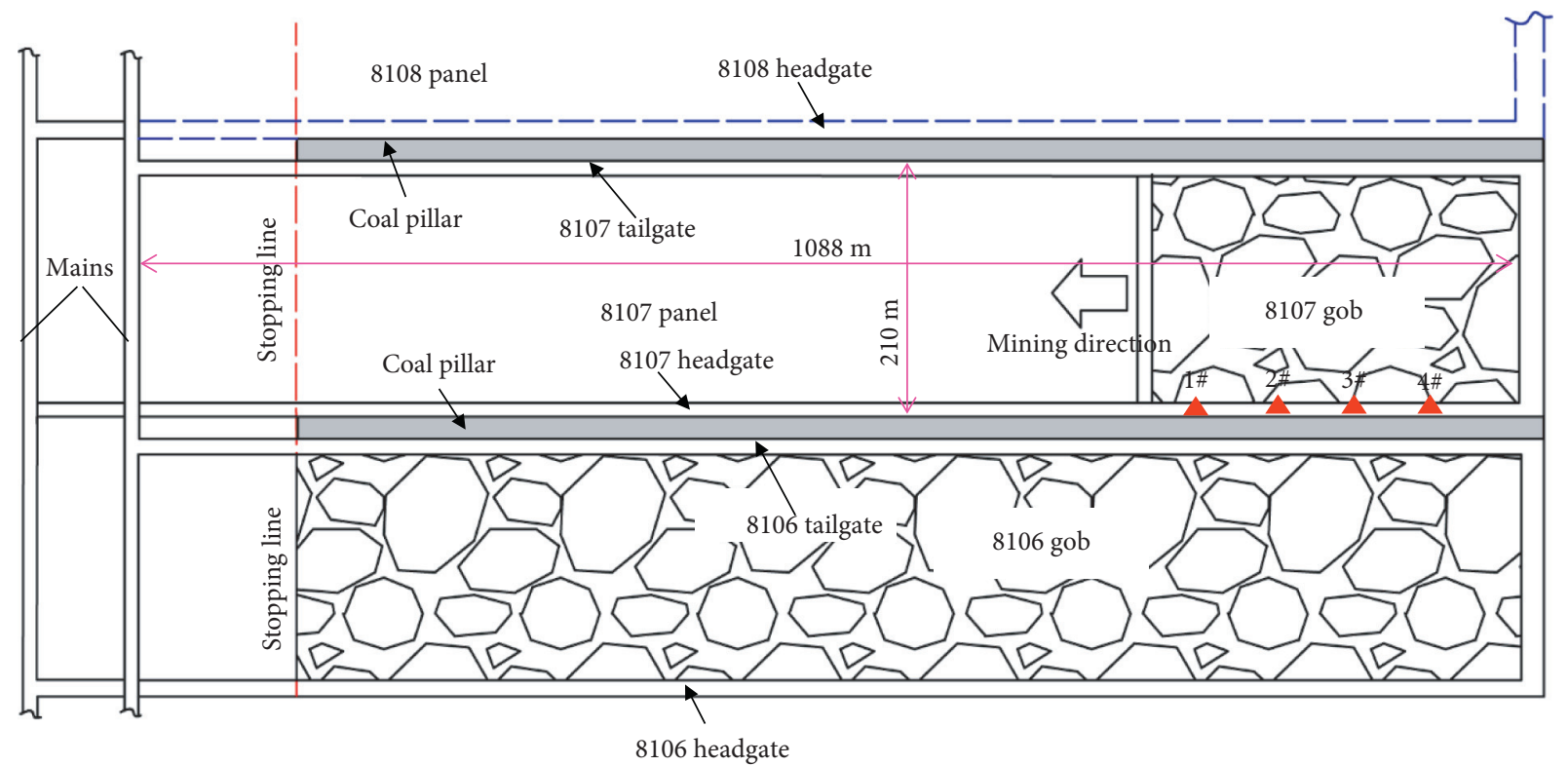

Displacement measuring station

Figure 2: Panels and roadway layout.

2\#. It can be seen from Figure 7(a) that the shallow area of the coal pillar is seriously damaged. A large number of massive fractures are present. Under the influence of high stress, the coal pillar has been entirely crushed and is in a yielded state. It is very likely that the failure of this coal pillar will lead to the collapse of the roadway.

\subsection{Analysis of Roof Strata Movement and Fracturing Height}

2.2.1. Movement of Roadway Roof Strata. After adjacent panel retreat, the roadway roof strata movement can be divided into three stages-the initial movement, the fracture, and the rotation of the strata-as shown in Figure 8. In the 


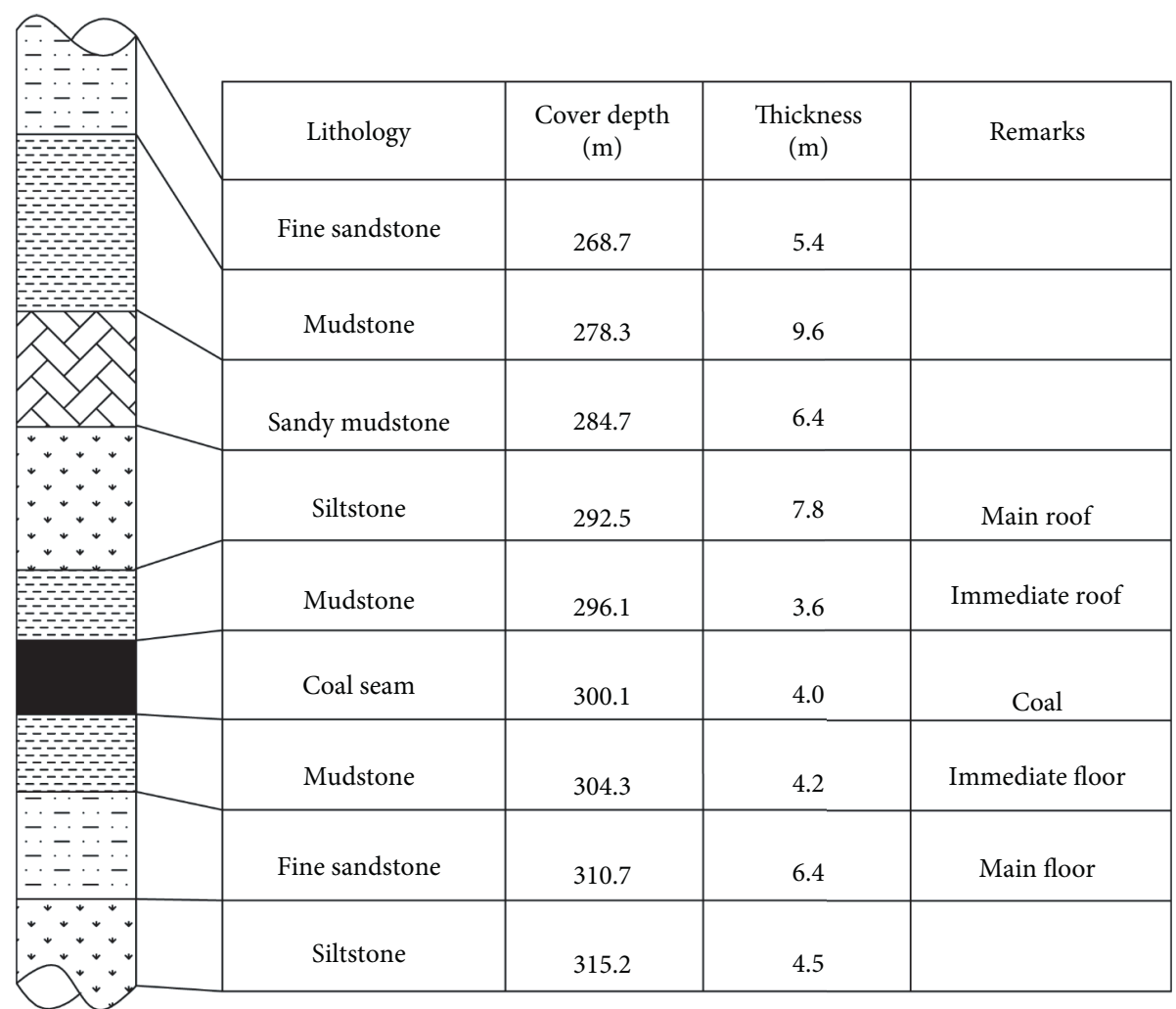

FIgURE 3: Rock histogram of the study site.

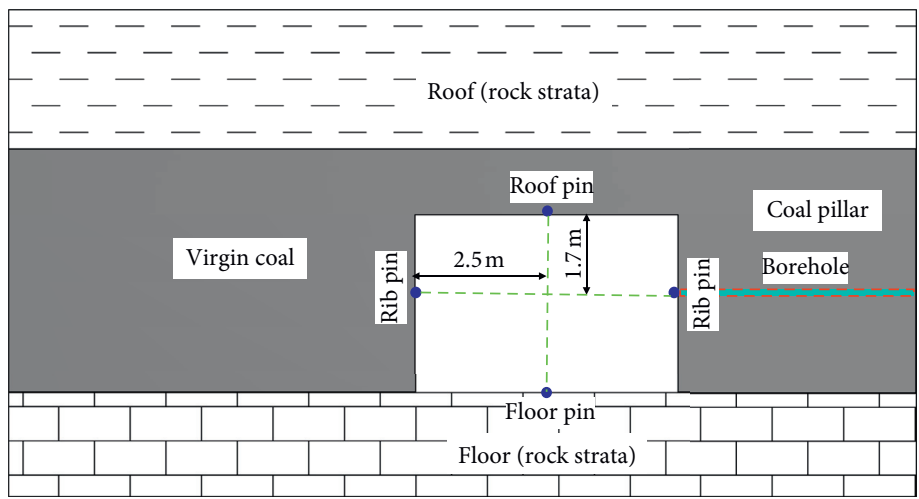

(a)

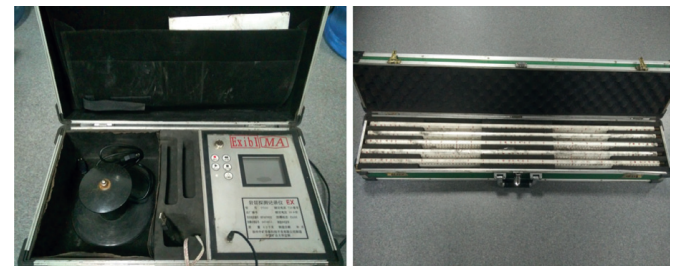

Rock layer detection recorder

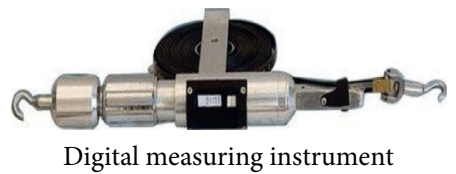

(b)

FIGURE 4: Schematic diagram for roadway measurements. (a) Cross section of the measurement station. (b) Measurement devices.

initial movement stage, the caving of the immediate roof occurs instantly after coal seam mining (Figure $8(\mathrm{a})$ ). In the fracture stage, the main roof fractures, as shown in Figure 8 (b). The roof and pillar begin to deform, and the overlying strata load is transferred to the virgin coal rib. Meanwhile, there is a crushing zone in the virgin rib edge. In the rotation stage, the main and immediate roofs rotate, with the fracture site as the axis of rotational motion (Figure 8(c)). Moreover, the stress from the roof strata is shifted gradually from the virgin coal rib to the coal pillar. Coal pillar failure will directly lead to a loss of stability in the roadway surrounding rock when the coal pillar is not strong enough to withstand the overlying strata load.
Since the movements of the roadway and gob roofs are closely related, the rotary subsidence of roof strata is the main reason for the high stress and deformation of the roadway. Hence, a novel approach has been proposed that can improve the stability of surrounding rock by interrupting the stress transmission. As shown in Figure 9, by adopting a directional fracturing line to cut off the gob roof, the stress propagating from there can be interrupted, relieving the high stress of the roadway roof. In addition, due to the rock mass gravity action, the gob roof strata collapse rapidly along the fracturing line. The rock masses rotate, come into contact in the process of collapse, and are broken into smaller rock masses (Figure 9). The rock masses in the 


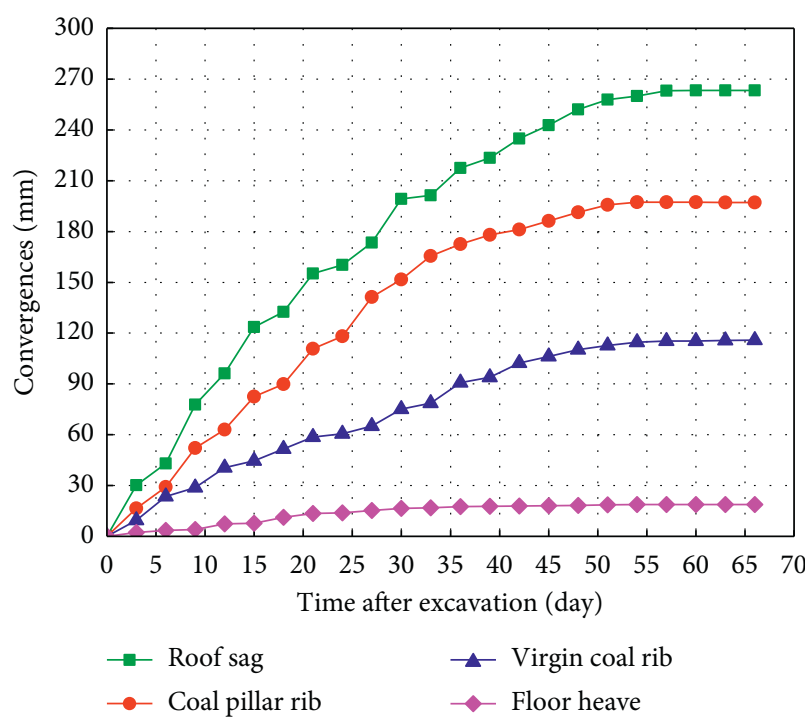

(a)

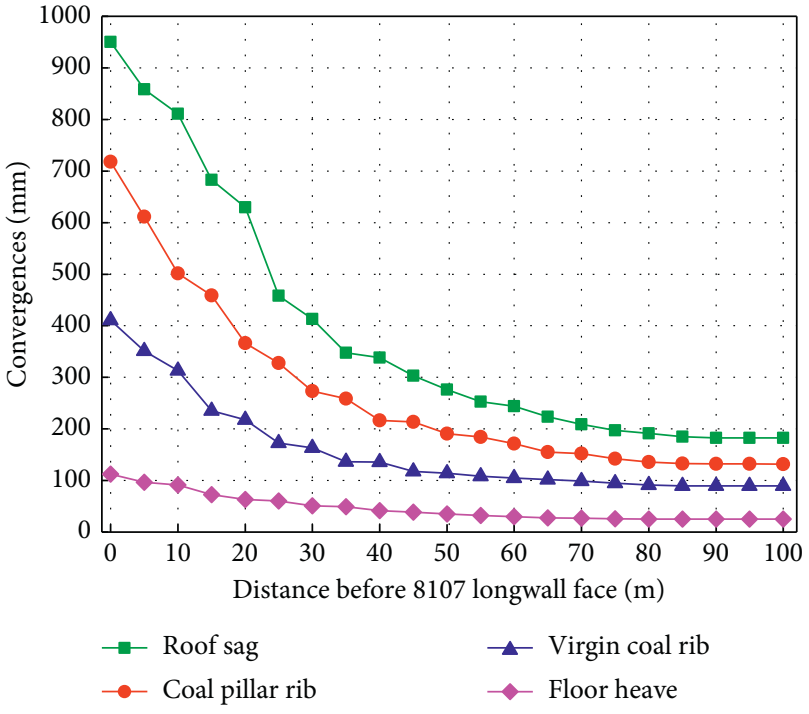

(b)

FIgURE 5: Measured convergences in the 8107 headgate. (a) During the 8107 headgate excavation. (b) During the 8107 panel retreat.

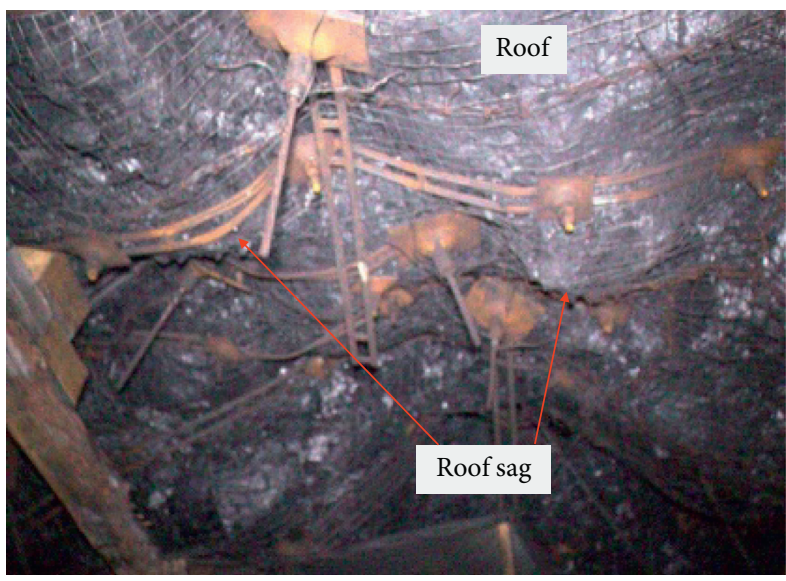

(a)

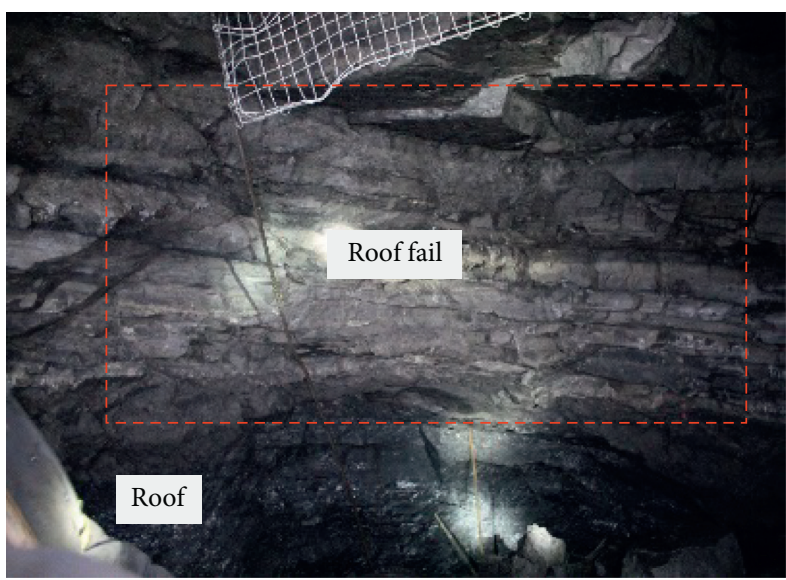

(c)

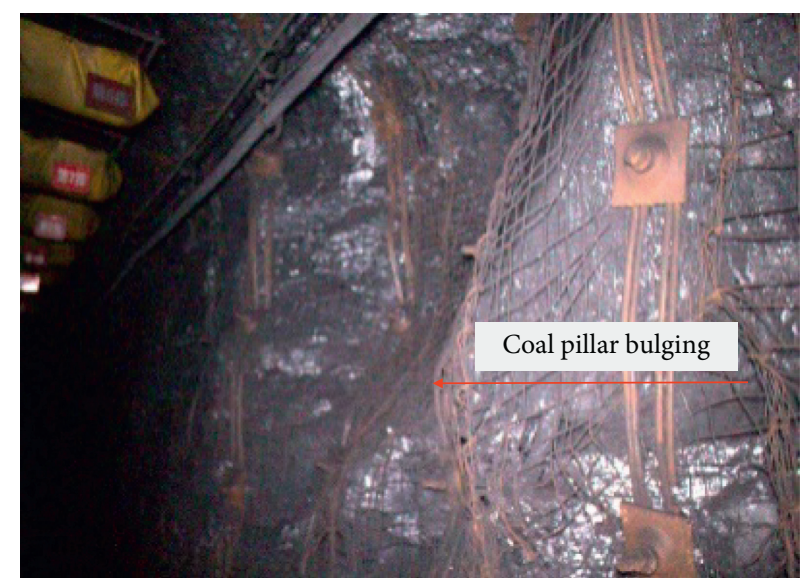

(b)

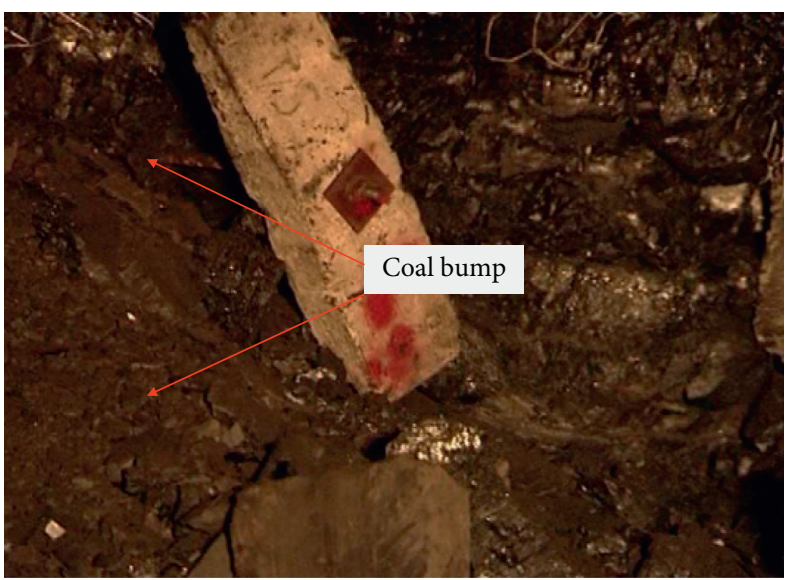

(d)

FIgURE 6: The deformation failure of the 8107 headgate. (a) Roof sag. (b) Coal pillar bulging. (c) Roof fail. (d) Coal bump. 


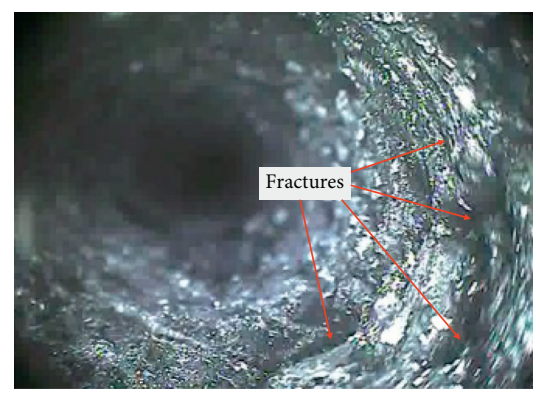

(a)

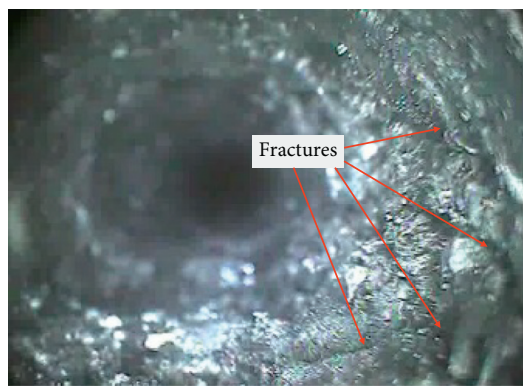

(b)

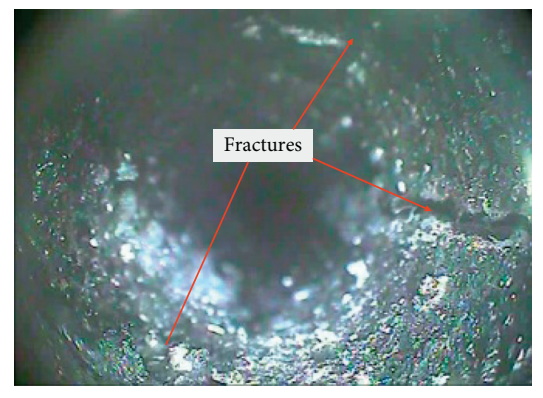

(c)

Figure 7: Photographs of a coal pillar with different borehole depths obtained by a rock layer detection recorder. (a) Borehole depth of 2 (m). (b) Borehole depth of $4 \mathrm{~m}$. (c) Borehole depth of $6 \mathrm{~m}$.

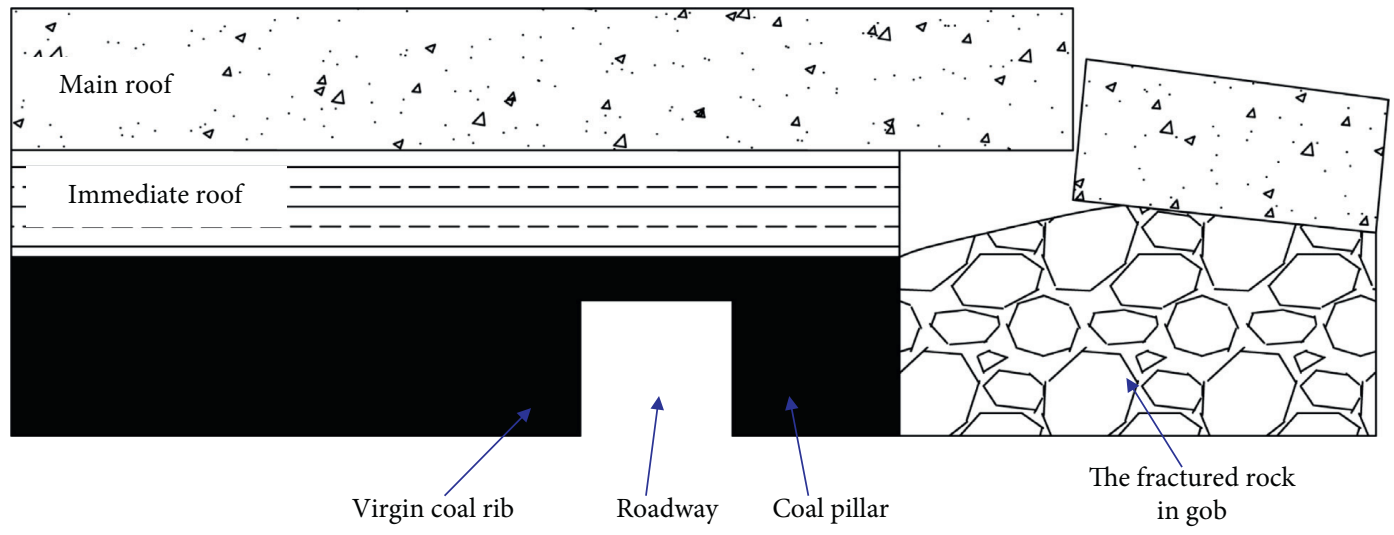

(a)

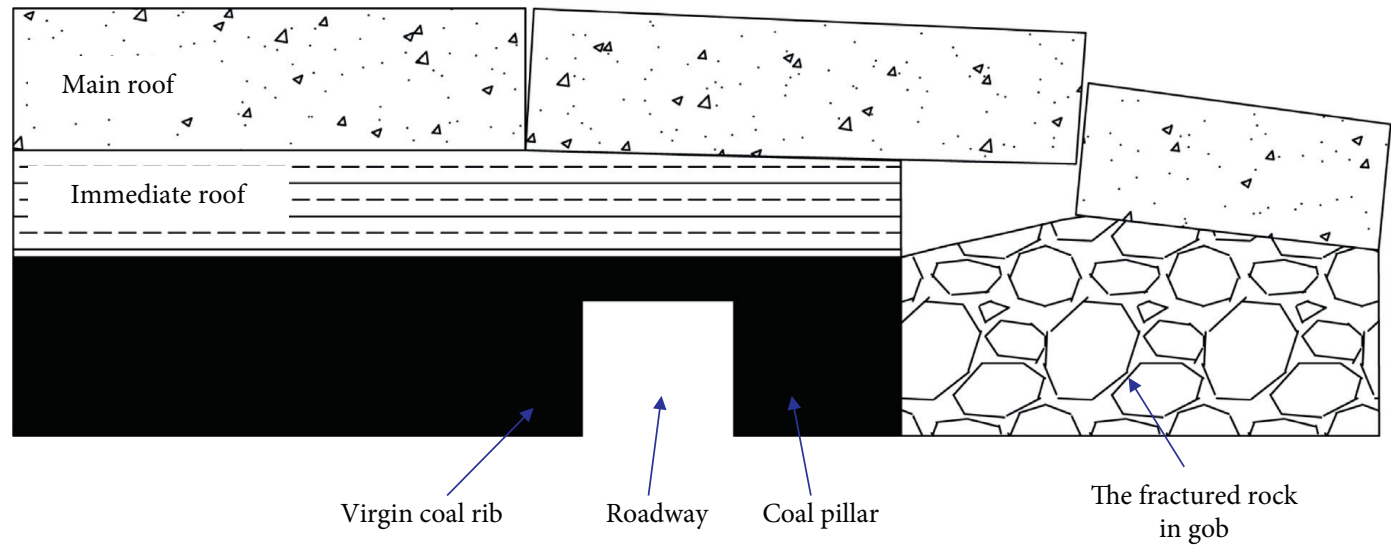

(b)

Figure 8: Continued. 


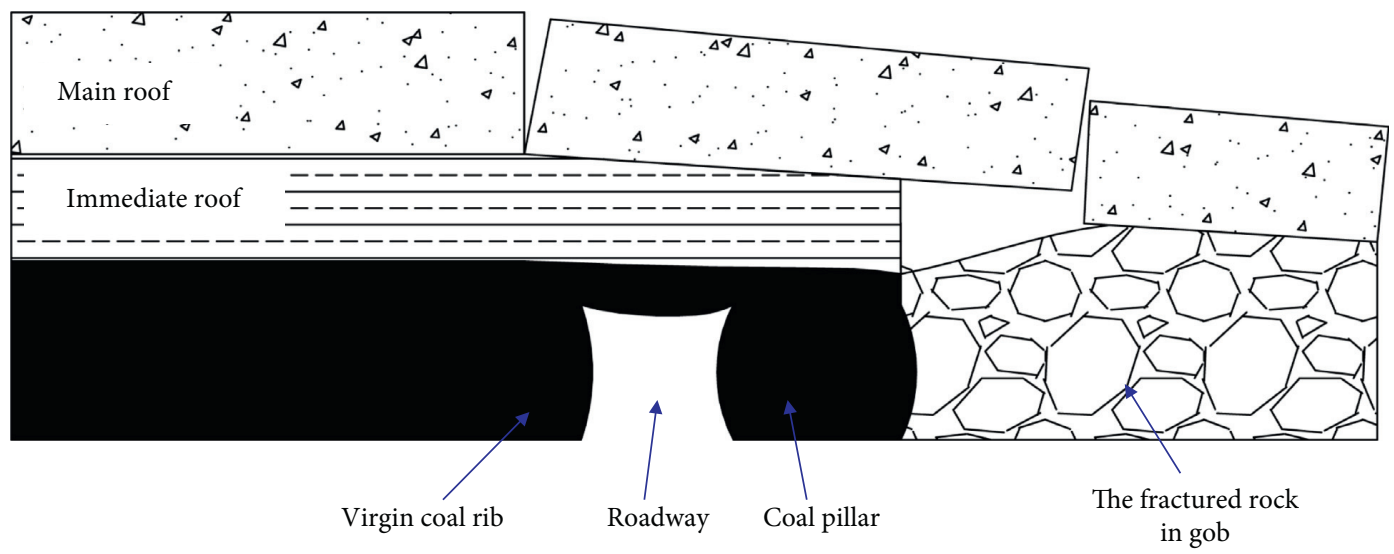

(c)

Figure 8: The movement process of roadway roof strata. (a) Initial movement of the strata. (b) Fracturing of the strata. (c) Rotation of the strata.

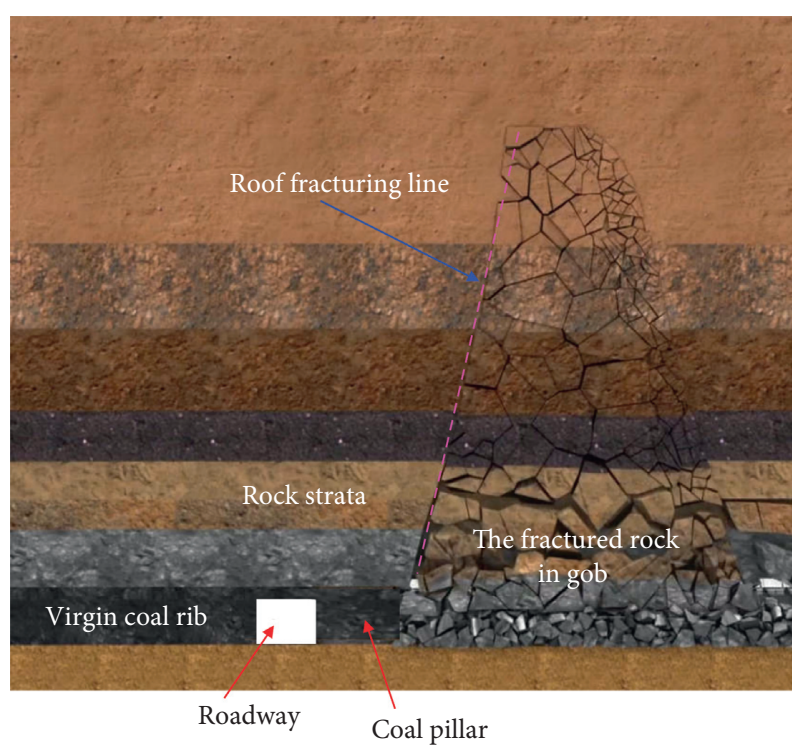

FIGURE 9: A novel approach for improving the stress environment of the roadway.

broken state increase and fill the gob. The broken rock masses in the gob are compressed to form a wedge accumulation structure that bears the overburden pressure, which effectively alleviates the stress concentration on the two ribs of the roadway.

\subsubsection{Determination of Fracturing Height for Roof Strata.} As the working face advances, the roof strata are cut off with guidance of the fracturing line. The collapsed rock breaks apart and fills the gob. In other words, the pile height of the fractured rock mass is greater than its original height. The collapsed rock pile height is closely related to the bulking factor $K_{p}$. The original height of the intact rock is $\Sigma h$, and the rock mass pile height after roof strata collapse is $K_{p} \Sigma h$. The void height between the pile and the stable overlying stratum is

$$
\Delta=\sum h+M-K_{p} \sum h=M-\sum h\left(K_{p}-1\right),
$$

where $\Delta$ delegates the void height between the fractured rock and the overlying intact rock in the gob; $M$ delegates the coal seam height; and $K_{p}$ delegates the bulking factor.

From equation (1), when $\Delta=0, M=\sum h\left(K_{p}-1\right)$. Therefore, the fracturing height of the roof strata is calculated by the following equation [18-20]:

$$
\sum h=\frac{M}{K_{p}-1},
$$

where $K_{p}=\left(M+h_{c r}\right) / h_{c r}$ and $h_{c r}$ is the height of the caved zones.

The height of the coal seam in the 8107 panel is $4 \mathrm{~m}$. The corresponding caved zone height is $15.9 \mathrm{~m}$ based on field measurements. According to equation (2), the bulking factor is 1.25 and the fracturing height of the roof strata is $16 \mathrm{~m}$.

\section{Discrete Element Numerical Simulation}

3.1. UDEC Simulation Method. Due to the joints and bedding planes in the rock mass, the finite element method (FEM) fails to accurately represent the nonlinear mechanical behaviours of the surrounding rock. UDEC can reveal the failure state of the surrounding rock by simulating the fracture, motion, and diastrophism for rock masses [21]. Rock simulated by UDEC could be expressed by block assemblies hinged to each other through contacts, which can precisely simulate the integrity of rock masses.

The destruction modes of contacts between the blocks include tensile damage and shear damage, which are judged according to the tensile strength, cohesion, and friction angle of contacts. The corresponding relationship of stress and displacement is dominated by the normal stiffness $\left(k_{n}\right)$ along the contact normal direction:

$$
\Delta \sigma_{n}=-k_{n} \Delta u_{n},
$$

where $\Delta \sigma_{n}$ is the incremental part of the normal stress and $\Delta u_{n}$ is the incremental part of the normal displacement. For 
the contact, if the stress in normal direction surpasses the tensile strength, $\sigma_{n}=0$.

The contact is controlled by the shear stiffness $\left(k_{\mathrm{s}}\right)$ and shear strength $\left(\tau_{\max }\right)$ along the tangential direction. At the same time, the cohesion $(C)$ and friction angle $(\phi)$ collectively determine the shear strength $\tau_{s}$.

If

$$
\left|\tau_{s}\right| \leq c+\sigma_{n} \tan \theta=\tau_{\max }
$$

then

$$
\Delta \tau_{s}=k_{s} \Delta u_{s}^{e}
$$

and, else, if

$$
\left|\tau_{s}\right| \geq \tau_{\max }
$$

then

$$
\tau_{s}=\operatorname{sign}\left(\Delta u_{s}\right) \tau_{\max },
$$

where $\Delta u_{e}^{s}$ is the shear displacement elastic incremental part and $\Delta u_{s}$ is the total shear displacement incremental part.

3.2. Validation of the Microscopic Parameters in the UDEC Model. The determination of the material parameters assigned in a UDEC model is fundamental for ensuring the accuracy of the numerical simulation results. The field rock mass consists of intact rock and fissures, and its strength is often lower than that obtained in the laboratory. Table 1 lists the mechanical parameters of the intact rock mass based on laboratory tests. The rock quality design (RQD) index is used to establish the relationship between laboratory and field data, and the relationship between the elasticity modulus of the intact rock and field rock mass can be expressed as follows [22]:

$$
\frac{E_{m}}{E_{r}}=10^{0.0186 R Q D-1.91},
$$

where $E_{m}$ represents the elasticity modulus of the rock mass in the field, $E_{r}$ represents the elasticity modulus of the intact rock, and RQD is the rock quality design index.

Based on a large number of field tests, Singh and Seshagiri established the relationship of the ratio of the uniaxial compressive strength and the ratio of the elastic modulus between the field rock mass and the intact rock:

$$
\frac{\sigma_{\mathrm{cm}}}{\sigma_{c}}=\left(\frac{E_{m}}{E_{r}}\right)^{k},
$$

where $\sigma_{c m}$ and $\sigma_{c}$ are the uniaxial compressive strengths of the field rock mass and the intact rock, respectively. $K$ is a coefficient related to the geological conditions of the study area and is determined to be 0.65 [23].

According to equations (8) and (9) and Table 1, the strength of the field rock mass can be calculated, as presented in Table 2. RQD is assessed using images from the rock layer detection recorder. The tensile strength is estimated to be $1 /$ 10 of the rock mass compressive strength.
A fitting method adopted in previous related studies was used to acquire block contacts data $[24,25]$. To obtain the mechanical parameters of block contacts, many simulated uniaxial compression tests on synthetic rock specimens were adopted in this paper, as shown in Figure 10. To eliminate the influence of mesh size, each type of calibrated model had an identical block mesh size which corresponded to the rock mass of the full model when the calibration was performed. Moreover, the calibrated model kept the height-to-width ratio constant during the calibration process. To ensure the reliability of the parameters, simulations were repeatedly checked until the modelling results matched the main properties of the field rock mass (uniaxial compressive strength and elasticity modulus). The target and simulated elasticity modulus and compressive strengths are compared in Table 3. These comparisons show that the simulated elasticity modulus and compressive strength are consistent with the target values. Table 4 lists the mechanical parameters of the rock mass used in the UDEC model. Therefore, the parameters listed in Table 4 could be applied to the simulations of the surrounding rock along roadways because the mechanical behaviour of the blocks was consistent with those of the field rock mass.

3.3. Model Establishment and Simulation Scheme. The main aim of this study is to investigate the stability of roadways under the influence of roof fracturing. A UDEC numerical model was established, and its dimensions were $100 \mathrm{~m} \times 60 \mathrm{~m}$ (Figure 11). The model consisted of the 8106 and 8107 panels and the roadway systems between them.

For the model, the horizontal lateral displacements were fixed. The displacements in the horizontal and vertical directions were restrained at bottom boundary. In the model, the Mohr-Coulomb criterion was selected. A vertical stress of $7.5 \mathrm{MPa}$ was applied on the top boundary of the UDEC model to represent the overlying rock load.

The numerical simulation consisted of three steps. (1) Model stress state balance and 8106 tailgate excavation: this was performed by deletion of the blocks representing the roadway. (2) Under the conditions of roof fracturing and no roof fracturing, the 8107 headgate was excavated. (3) The 8106 panel was extracted from the right to the left of the model, and each extraction was $10 \mathrm{~m}$.

\section{Simulation Results and Discussion}

4.1. Determination of Roof Fracturing Angle in Roadway. The stability of the surrounding rock is influenced by roofs movement above the roadway. Meanwhile, the roof fracturing angle is vital to reduce the load and release the roadway roof pressure in the strata movement process. A suitable roof fracturing angle is not only conducive to the continual collapse of the strata, but also to alleviate the stress concentration of the surrounding rock and reduce the deformation of the roadway roof. Figure 12 shows the displacement rules of different roadway roof heights $(0.5 \mathrm{~m}$, $1 \mathrm{~m}$, and $1.5 \mathrm{~m}$ ) under the conditions of various roof fracturing angles. 
TABLe 1: The mechanical parameters of the intact rock mass.

\begin{tabular}{|c|c|c|c|c|c|c|}
\hline Lithology & $\begin{array}{l}\text { Density } \\
\left(\mathrm{kg} / \mathrm{m}^{3}\right)\end{array}$ & $\begin{array}{c}\text { Compressive strength } \\
(\mathrm{MPa})\end{array}$ & $\begin{array}{l}\text { Elasticity modulus } \\
(\mathrm{GPa})\end{array}$ & $\begin{array}{l}\text { Poisson's } \\
\text { ration }\end{array}$ & $\begin{array}{l}\text { Cohesion } \\
(\mathrm{MPa})\end{array}$ & Friction $\left({ }^{\circ}\right)$ \\
\hline Fine sandstone & 2750 & 57.2 & 12.5 & 0.22 & 2.6 & 29 \\
\hline Mudstone & 1900 & 13.1 & 5.0 & 0.29 & 1.4 & 25 \\
\hline $\begin{array}{l}\text { Sandy } \\
\text { mudstone }\end{array}$ & 2450 & 27.8 & 7.1 & 0.26 & 1.8 & 27 \\
\hline Siltstone & 2680 & 47.6 & 9.8 & 0.24 & 2.3 & 31 \\
\hline Mudstone & 1900 & 13.1 & 5.0 & 0.29 & 1.4 & 25 \\
\hline Coal seam & 1600 & 9.8 & 1.5 & 0.32 & 0.8 & 22 \\
\hline Mudstone & 1900 & 13.1 & 5.0 & 0.29 & 1.4 & 25 \\
\hline Fine sandstone & 2750 & 57.2 & 12.5 & 0.22 & 2.6 & 29 \\
\hline Siltstone & 2680 & 47.6 & 9.8 & 0.24 & 2.3 & 31 \\
\hline
\end{tabular}

TABLE 2: The mechanical parameters of the rock mass.

\begin{tabular}{lcccc}
\hline Lithology & RQD & $E_{m}(\mathrm{GPa})$ & $\sigma_{c m}(\mathrm{MPa})$ & \\
\hline Fine sandstone & 93 & 8.3 & 43.5 & $\sigma_{t}(\mathrm{MPa})$ \\
Sandy mudstone & 90 & 4.1 & 19.5 & 4.3 \\
Siltstone & 89 & 5.5 & 32.8 & 1.9 \\
Mudstone & 85 & 2.3 & 7.6 & 3.2 \\
Coal seam & 71 & 0.4 & 4.1 & 0.7 \\
\hline
\end{tabular}

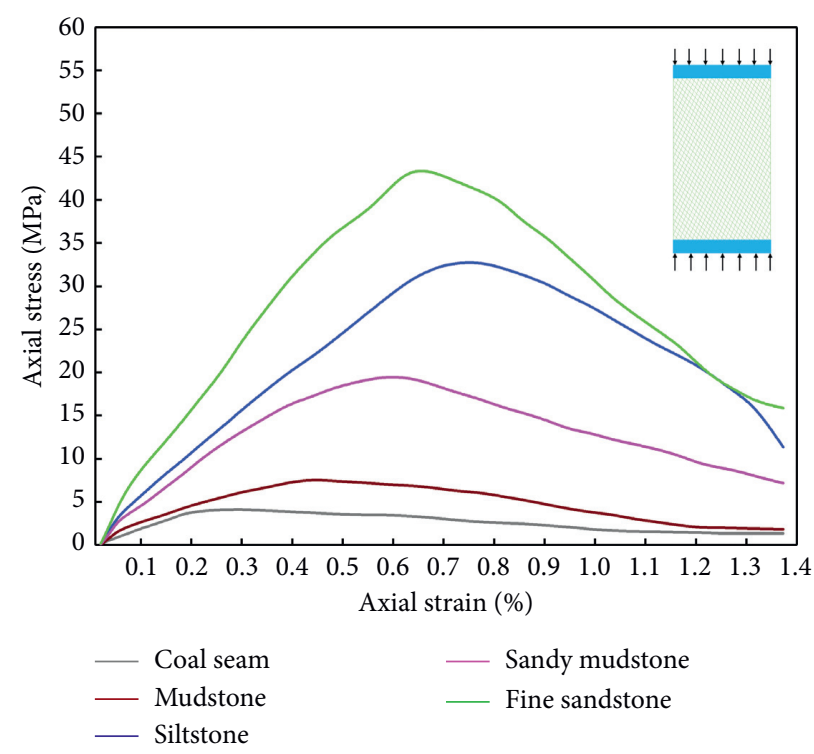

FIgURE 10: Axial stress-strain curves of the synthetic rock specimens.

As illustrated in Figure 12(a), when the roof was not fractured, a large separation zone appeared in the roadway roof, and a distinct suspended roof structure formed above the roadway. The displacements for the roof height of $0.5 \mathrm{~m}$, $1 \mathrm{~m}$, and $1.5 \mathrm{~m}$ were $932 \mathrm{~mm}, 805 \mathrm{~mm}$, and $711 \mathrm{~mm}$, respectively, which easily led to roof rock falling. When the fracturing angle was $5^{\circ}$, the roof strata of the gob could not fully collapse along the fracturing line, which could easily cause dynamic disturbance to the roadway. The displacements of the three corresponding roof heights were $259 \mathrm{~mm}$, $236 \mathrm{~mm}$, and $221 \mathrm{~mm}$. Meanwhile, the separation area of the roof strata was reduced. When the fracturing angle was $10^{\circ}$, the roof strata collapsed along the fracturing line in a timely manner, and the fractured rock filled the gob and supported the overlying strata. The displacements of the $0.5 \mathrm{~m}$ and $1 \mathrm{~m}$ roof heights were continuously reduced (Figure 12(c)), and the deformation of roof strata was consistent among the different regions, which further controlled the development of roof strata separation. As the fracturing angle was $15^{\circ}$ and $20^{\circ}$, respectively, the range of the suspended roofs above the roadway enhanced with increasing fracturing angle, which led to an increase in the load borne by the roof rock. Compared with the roof deformation conditions of a fracturing angel of $10^{\circ}$, with a greater fracturing angle, the damage scope of the roof rock was enlarged, and the displacement of the roadway roof strata continuously increases (Figures 12(d) and 12(e)), which had a negative effect on maintaining the stability of the roadway surrounding rock. 
TABLE 3: Comparisons of the target and simulated elasticity modulus and compressive strengths.

\begin{tabular}{|c|c|c|c|c|c|c|}
\hline \multirow{2}{*}{ Lithology } & \multicolumn{3}{|c|}{$E_{m}(\mathrm{GPa})$} & \multicolumn{3}{|c|}{ Compressive strength $(\mathrm{MPa})$} \\
\hline & Target & Simulated & Error (\%) & Target & Simulated & Error (\%) \\
\hline Fine sandstone & 8.3 & 8.4 & 1 & 43.5 & 43.4 & 0.2 \\
\hline Sandy mudstone & 4.1 & 4.2 & 2 & 19.5 & 19.6 & 0.5 \\
\hline Siltstone & 5.5 & 5.4 & 2 & 32.8 & 32.6 & 0.6 \\
\hline Mudstone & 2.3 & 2.3 & 0 & 7.6 & 7.5 & 1 \\
\hline Coal seam & 0.4 & 0.4 & 0 & 4.1 & 4.2 & 2 \\
\hline
\end{tabular}

TABLE 4: The mechanical parameters of the rock mass used in the UDEC model.

\begin{tabular}{|c|c|c|c|c|c|c|c|}
\hline \multirow{2}{*}{ Lithology } & \multicolumn{3}{|c|}{ Block properties } & \multicolumn{4}{|c|}{ Contact properties } \\
\hline & Density $\left(\mathrm{kg} / \mathrm{m}^{3}\right)$ & $E(\mathrm{GPa})$ & $K_{n}(\mathrm{GPa} / \mathrm{m})$ & $k_{s}(\mathrm{GPa} / \mathrm{m})$ & $C(\mathrm{MPa})$ & $\varphi\left(^{\circ}\right)$ & $\sigma_{t}(\mathrm{MPa})$ \\
\hline Fine sandstone & 2750 & 8.3 & 286.2 & 114.5 & 2.3 & 31 & 4.3 \\
\hline Mudstone & 1900 & 2.2 & 112.4 & 45 & 1.2 & 28 & 0.7 \\
\hline Sandy mudstone & 2450 & 4.1 & 187.8 & 75.1 & 1.5 & 30 & 1.9 \\
\hline Siltstone & 2680 & 5.5 & 215.9 & 84.2 & 2.0 & 31 & 3.2 \\
\hline Mudstone & 1900 & 2.2 & 112.4 & 45 & 1.2 & 28 & 0.7 \\
\hline Coal seam & 1600 & 0.4 & 86.2 & 34.5 & 0.5 & 24 & 0.4 \\
\hline Mudstone & 1900 & 2.2 & 112.4 & 45 & 1.2 & 28 & 0.7 \\
\hline Fine sandstone & 2750 & 8.3 & 286.2 & 114.5 & 2.3 & 31 & 4.3 \\
\hline Siltstone & 2680 & 5.5 & 215.9 & 84.2 & 2.0 & 31 & 3.2 \\
\hline
\end{tabular}

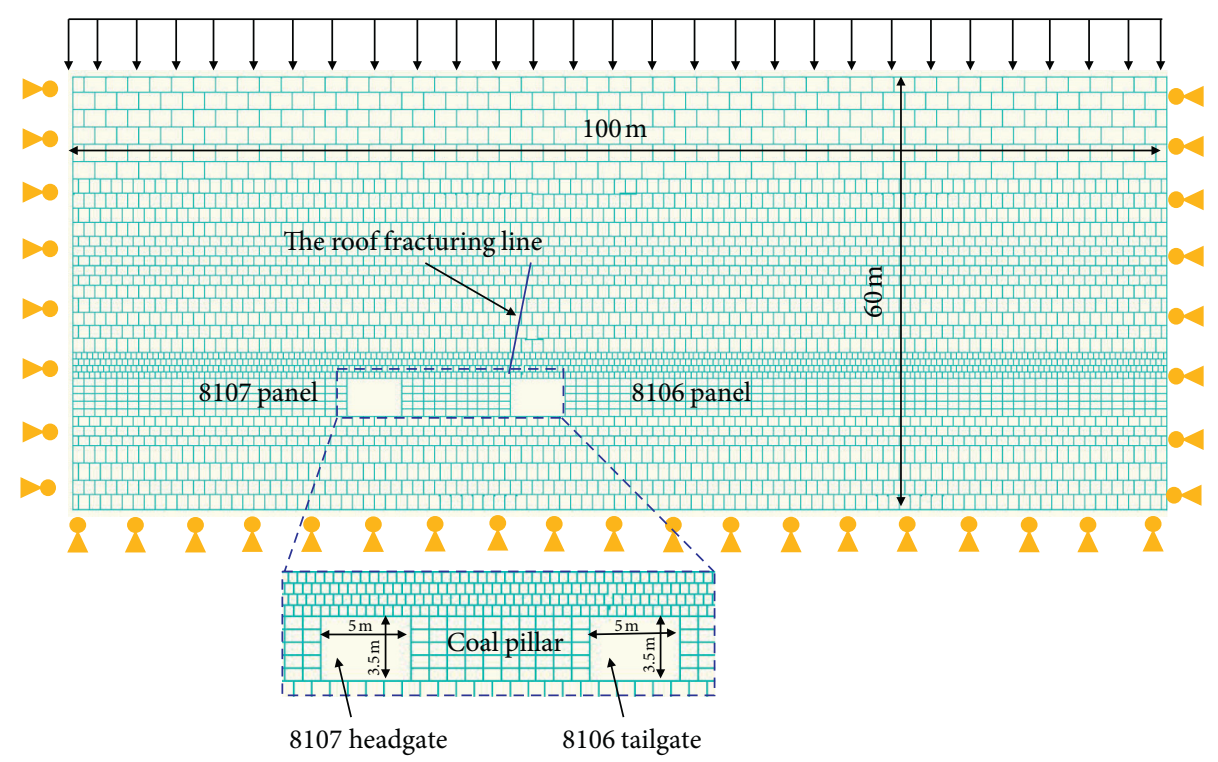

FIGURE 11: The UDEC numerical model.

According to the above discussion, the optimal fracturing angle of the roof strata was determined to be $10^{\circ}$, as shown in Figure 12(c).

4.2. Stress Changes in Two Roadway Ribs. Figure 13 shows the vertical stress distribution in the two roadway ribs at different stages with and without fracturing roof. It should be noted that the curve data for the right and left ribs were obtained at the midheight of the two ribs in the roadway. The modelling results show that the stress changes in the two roadway ribs are greatly affected by roof fracturing.

As shown in Figure 13(a), without roof fracturing, roadway excavation redistributed the stress in the coal pillar and virgin coal rib. The vertical stress increased to a peak and then decreased. The vertical stress peaks in the two roadway ribs were equal. In the panel retreat stage, stress concentrated in the two ribs. The vertical stress peak of the coal pillar exceeded the solid rib stress because the roadway roof strata rotated, and the overlying strata load was mainly carried by the coal pillar during the mining process. The roadway was in a state of high stress, which led to severe deformation of the roadway (Figure 6). As shown in Figure 13(b), with roof fracturing, the vertical stress of the two ribs in the roadway changed significantly in the process of panel extraction. As the roof strata stress transfer avenue was cut off, the vertical stress peak of the coal pillar decreased 


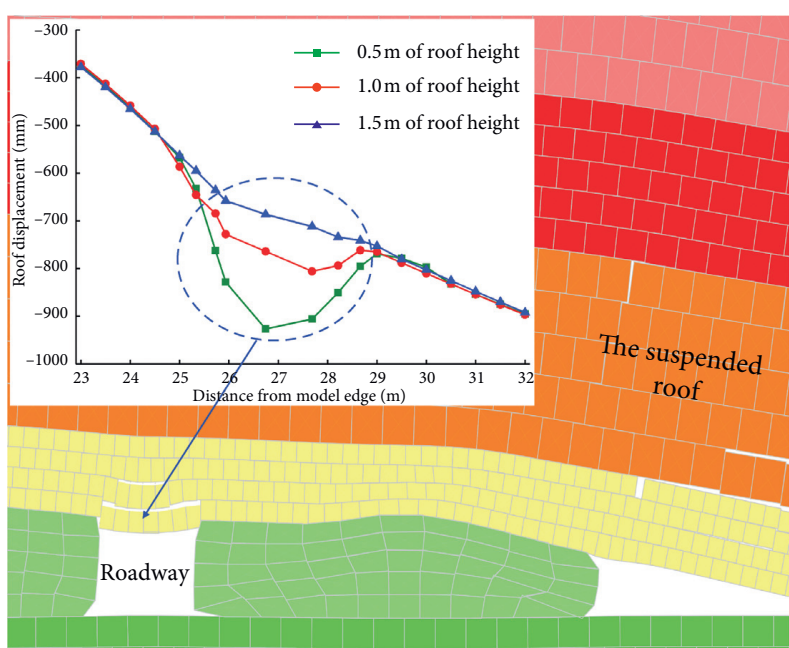

(a)

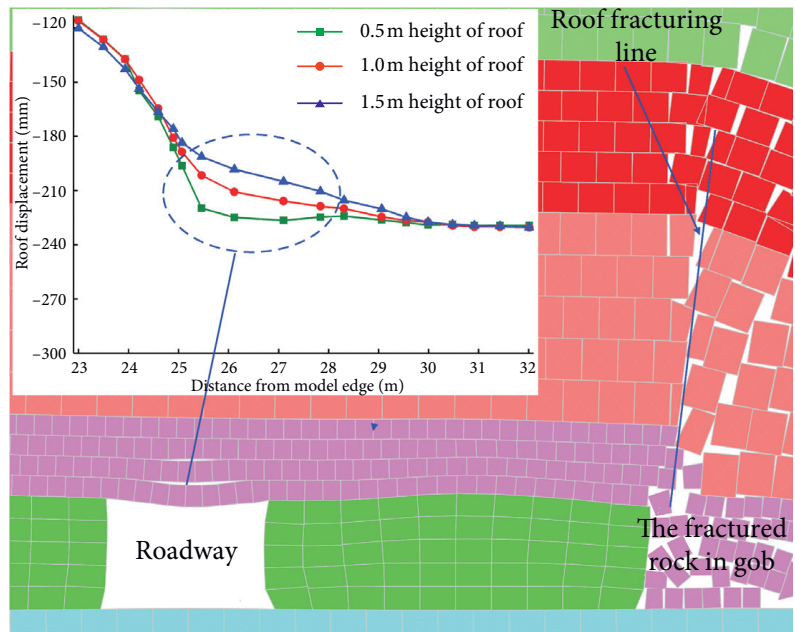

(c)

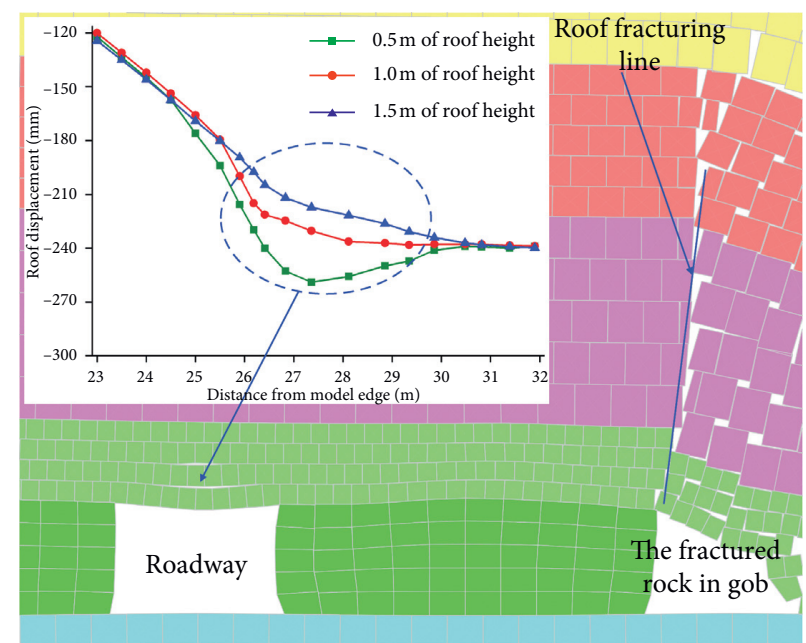

(b)

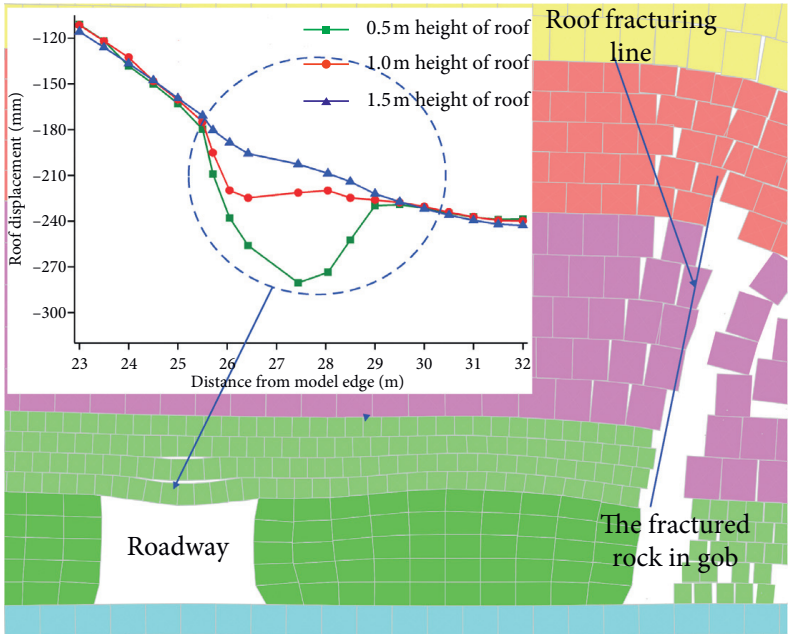

(d)

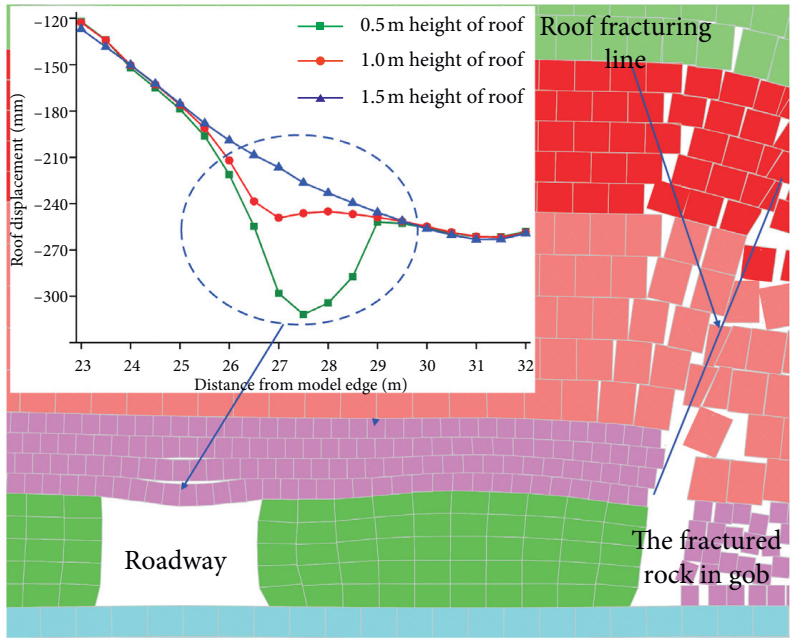

(e)

Figure 12: The deformation rules and fracture characteristics of roof strata under different roof fracturing conditions. (a) Nonfracturing roof. (b) $5^{\circ}$ roof fracturing angle. (c) $10^{\circ}$ roof fracturing angle. (d) $15^{\circ}$ roof fracturing angle. (e) $20^{\circ}$ roof fracturing angle. 


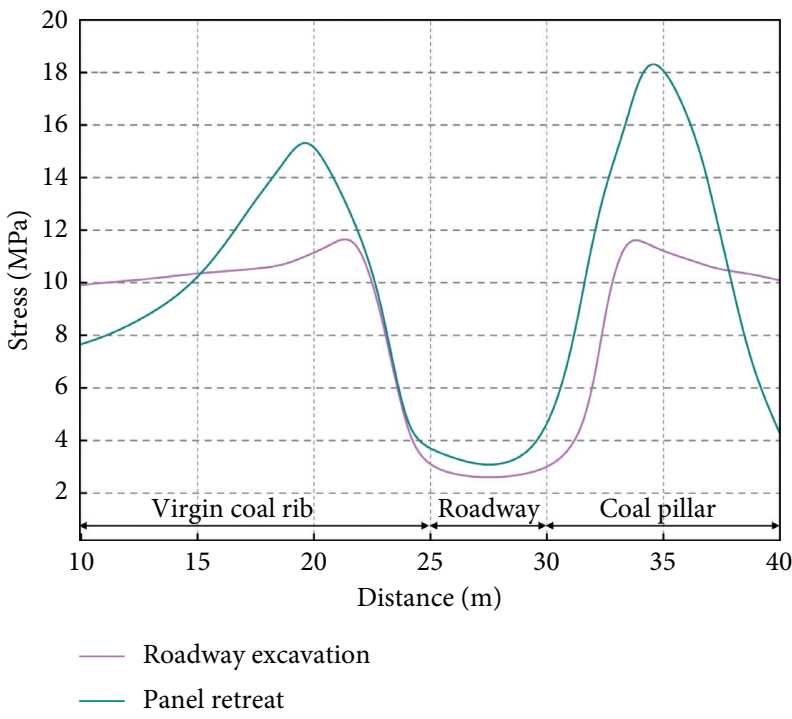

(a)

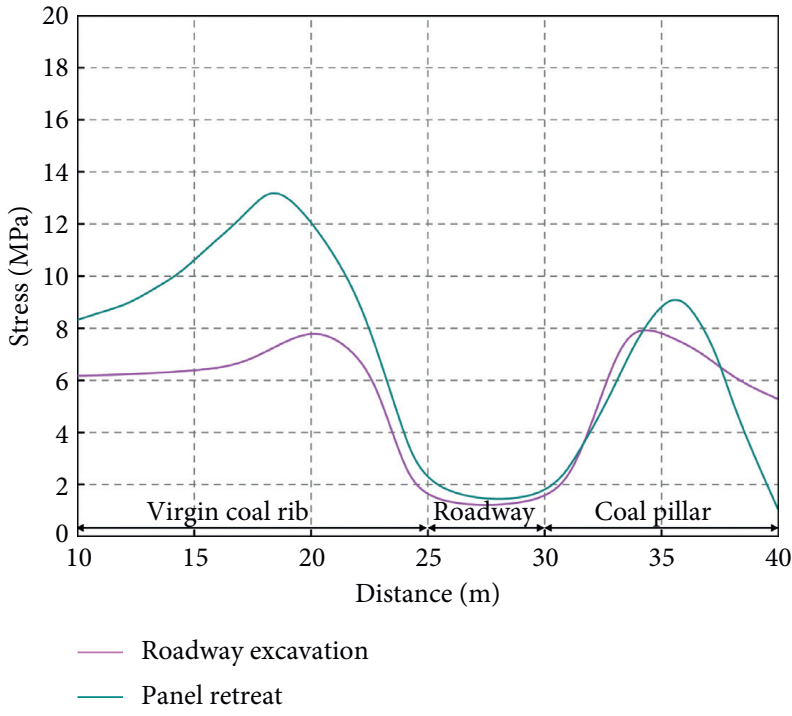

(b)

Figure 13: Vertical stress distribution of two roadway ribs at different stages. (a) Roof nonfracturing. (b) Roof fracturing.

from 18.3 $\mathrm{MPa}$ to $9.3 \mathrm{MPa}$, while the virgin rib stress decreased from 15.6 MPa to 13.4 MPa. Meanwhile, the bearing capacity of collapsed rock mass in the gob reduced the partial coal pillar pressure. Therefore, the coal pillar stress was clearly lower than that in the solid coal region. The stress environment of the roadway thus was optimized.

4.3. Stress Changes in the Roadway Roof. During the simulation, the evolution law of the vertical stress in the roadway roof was monitored. The monitoring points were placed $5 \mathrm{~m}$, $10 \mathrm{~m}, 15 \mathrm{~m}$, and $20 \mathrm{~m}$ above the roadway. Figure 14 shows the variations in vertical stress at different roof positions during mining. The vertical stress peaks under roof fracturing and roof nonfracturing conditions are marked by $\sigma_{A}$ and $\sigma_{\mathrm{B}}$, respectively.

As shown in Figures 14(a) and 14(b), under the influence of roof fracturing, the vertical stresses at $5 \mathrm{~m}$ and $10 \mathrm{~m}$ above the roadway were much smaller than the corresponding vertical stresses with roof nonfracturing. With the increase in height, the vertical stresses at $15 \mathrm{~m}$ and $20 \mathrm{~m}$ above the roadway under the condition of roof fracturing gradually approached the vertical stresses without roof fracturing, as shown in Figures 14(c) and 14(d). The simulation results show that, within the range of influence of the roof fracturing, the structural connectivity between the roadway and gob roofs was cut off, and the stress from the gob roof could not be transferred to the roadway roof. In the area far from the roof fracturing line, the roadway and gob roofs formed complete and continuous rock strata, which weakened the influence of roof fracturing on the stress in the upper complete rock mass.

4.4. Discussion of the Roadway Roof Mechanical Behaviour. After panel retreat, the roof strata structure above the roadway was broken, as shown in Figure 15(a). Rocks A, B, and C interact, which influences the stability of the 8107 headgate. According to the ultimate balance theory, the rock B geometry size $l$ can be calculated by the dip length $S$ of the panel and the periodic fracture length $L$ of the main roof, as follows [26-28]:

$$
l=\frac{2 L}{17}\left[\sqrt{\left(10 \frac{L}{S}\right)^{2}+102-10 \frac{L}{S}}\right],
$$

where $l$ refers to the geometry size of rock $\mathrm{B}, S$ is the dip length of the panel, and $L$ is the periodic fracture length of the main roof. From field measurements of the 8107 panel, the periodic fracture length of the main roof was $23 \mathrm{~m}$. The dip length of the 8107 panel was $210 \mathrm{~m}$. From equation (10), the rock B geometry size $l$ was $24.5 \mathrm{~m}$.

The geometry size of $24.5 \mathrm{~m}$ was greater than the total width of the roadway and pillar, and the roof above the roadway was suspended. This conclusion was basically consistent with the simulation result (Figure 12(a)). Because of the suspended roof effect, the stress distribution in roadway ribs presented a "double peak" shape (Figure 15(a)), which kept the 8107 headgate in a high-stress state. The upper stratum load exceeded the ultimate coal pillar strength, and the coal pillar experienced yield failure, which made the roadway unstable. Since the roof fracturing approach was adopted to cut off the suspended roof, the high stress of the two roadway ribs could be effectively released, as shown in Figure 15(b). At the same time, the fractured rock filled the gob and was in close contact with the upper rock structure, which limited the rotational deformation of the roadway roof and improved the coal pillar stability. The 8107 headgate was in a state of low stress.

\section{Field Application}

5.1. Establishment of Roof Fracturing Line. Currently, blasting is the primary method used to create roof fracturing lines. In the blasting process, an energy- 


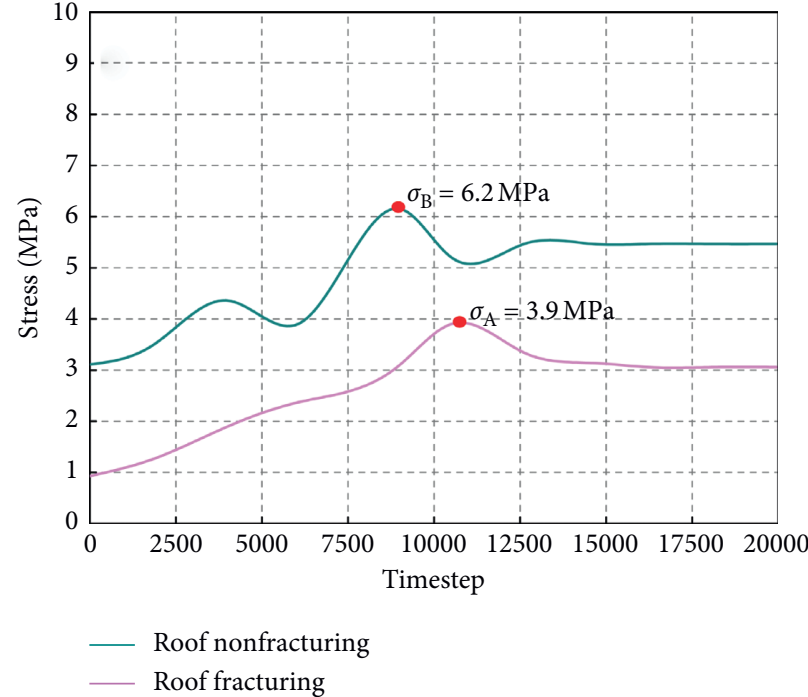

(a)

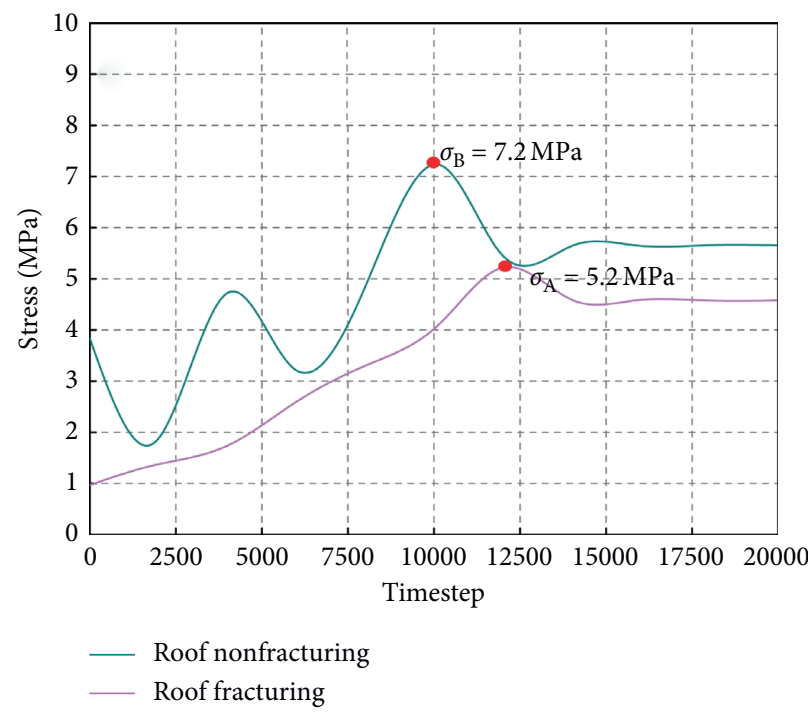

(c)

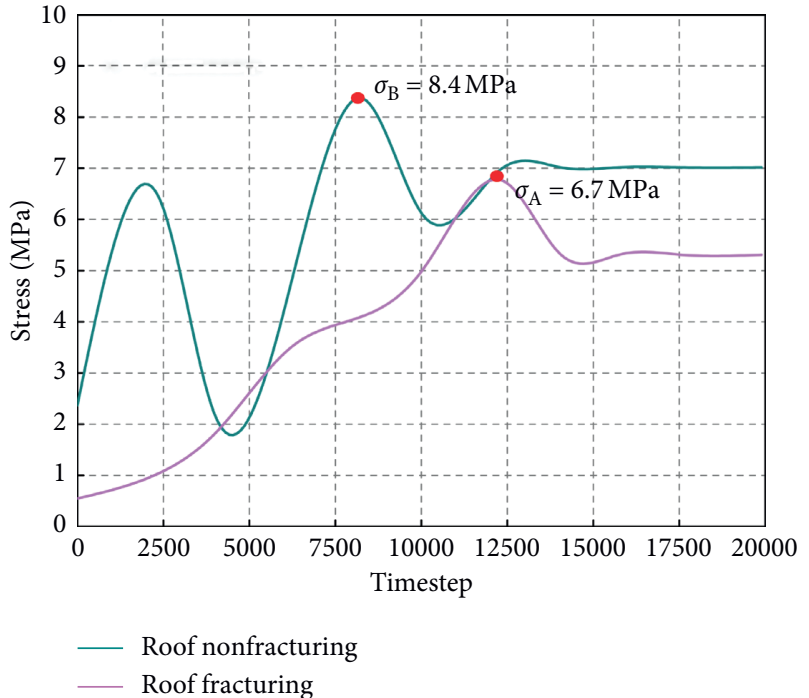

(b)

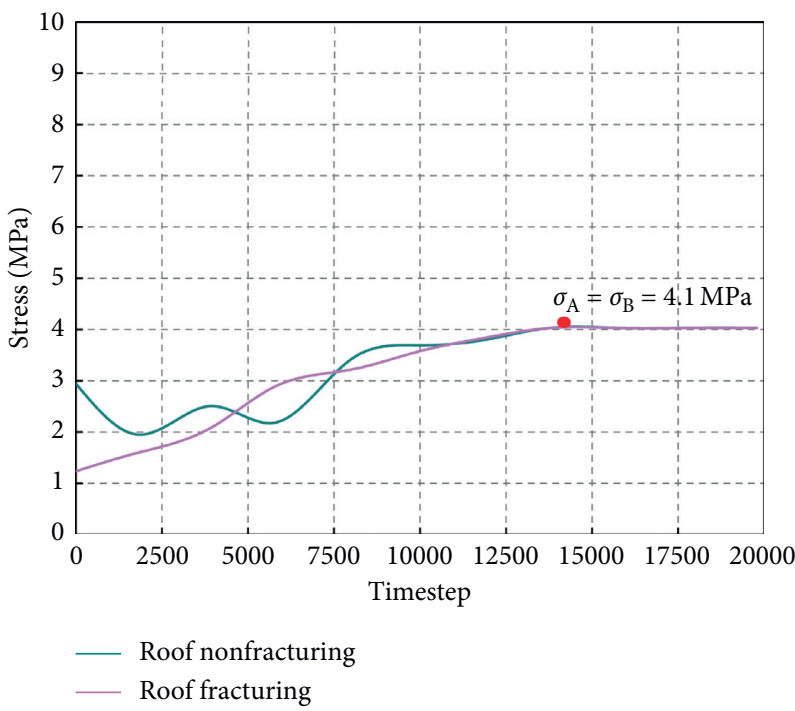

(d)

Figure 14: The vertical stress variations at different positions of the roof. (a) $5 \mathrm{~m}$. (b) $10 \mathrm{~m}$. (c) $15 \mathrm{~m}$. (d) $20 \mathrm{~m}$.

accumulated blasting device (Figure 16) is used to establish rock fracturing cracks. Through the blasting devices, high-temperature, high-pressure, and high sound velocity gases generated by blasting create a fracture in a predetermined direction of the rock mass, with no damage impact in other directions. Figure 17 shows the fracture propagation due to blasting.

To verify the feasibility of roof fracturing for deep high-stress roadways, a field test was carried out. Blasting was undertaken in front of the 8107 tailgate roof to create a fracturing line, as shown in Figure 18. The gob roof strata collapsed quickly along the fracturing line with the retreat of the 8107 panel. The broken rock masses filled the gob and were in contact with the upper strata.

5.2. Roadway Deformation Law. The deformation of rock surrounding the 8108 headgate was measured during the excavation of the roadway and panel retreat, as shown in Figures 19(a) and 19(b). Within 50 days of excavation, the deformation of the surrounding rock increased rapidly with the stress adjustment. After 50 days of excavation, the deformation of the roadway gradually decreased and tended to stabilize. The final convergences of the roof, coal pillar rib, and virgin coal rib were $95 \mathrm{~mm}, 78 \mathrm{~mm}$, and $60 \mathrm{~mm}$, respectively. During the 8108 panel retreat, roadway deformation mainly occurred $60 \mathrm{~m}$ in front of the working face; the total convergences of the roof, coal pillar rib, and virgin coal rib reached, respectively, $242 \mathrm{~mm}, 169 \mathrm{~mm}$, and $126 \mathrm{~mm}$. Compared with the roadway deformation without fracturing roof, the corresponding convergence of the roadway (roof, pillar, and virgin rib) was reduced by $75 \%$, $76 \%$, and $70 \%$, respectively. The stability of the 8108 headgate was obviously improved, as shown in Figure 20. The field measurements indicate that severe roadway 


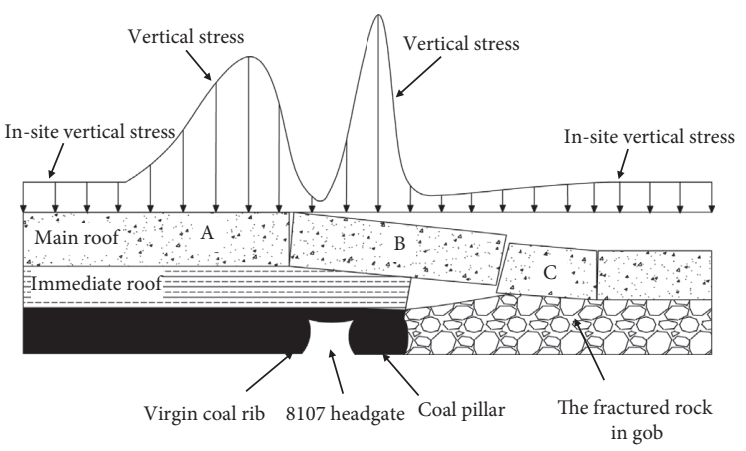

(a)

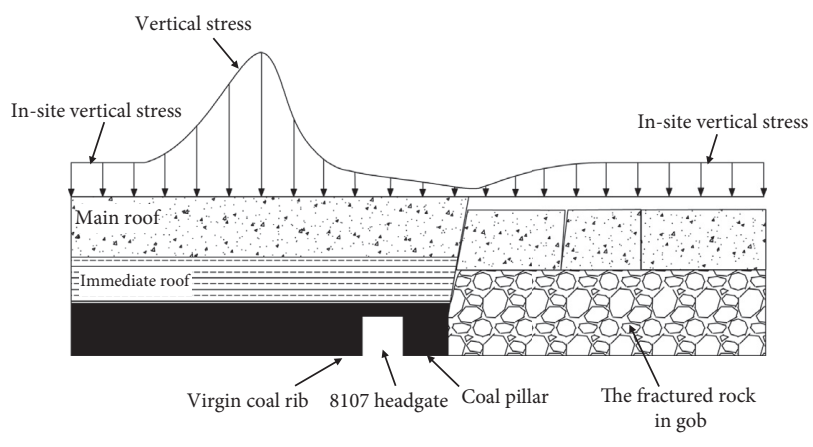

(b)

FIGURE 15: Failure analysis of surrounding rock in roadway. (a) Before roof fracturing. (b) After roof fracturing.

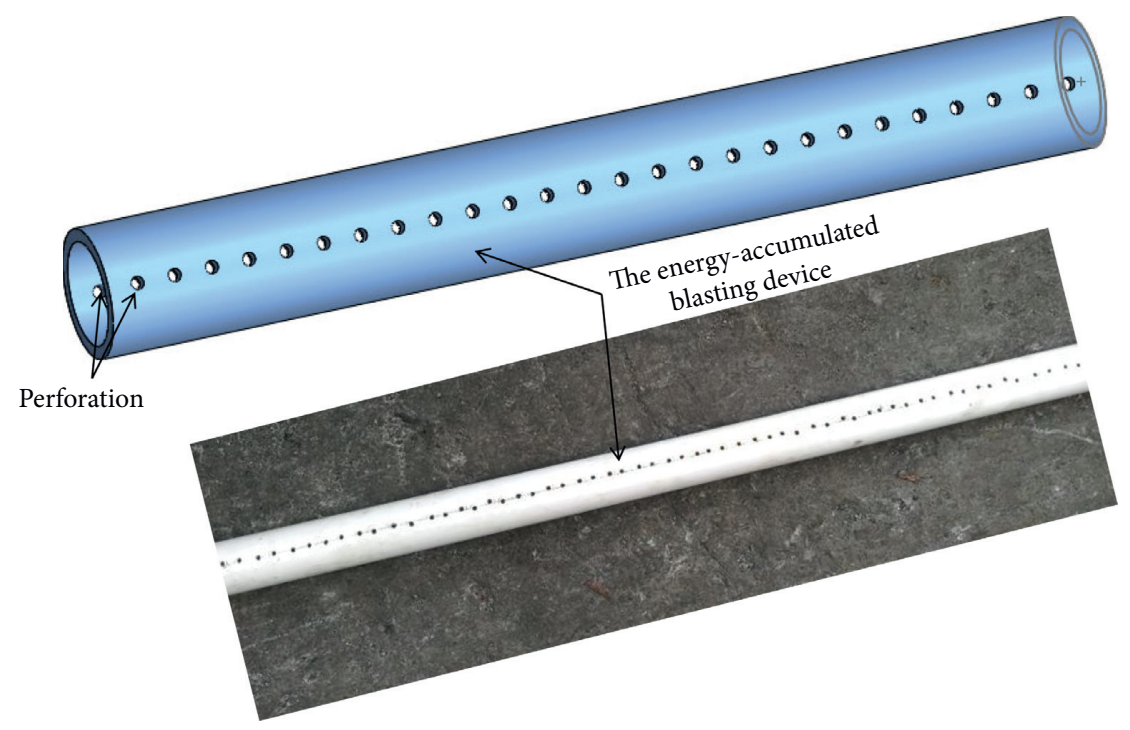

FIGURE 16: The energy-accumulated blasting device.

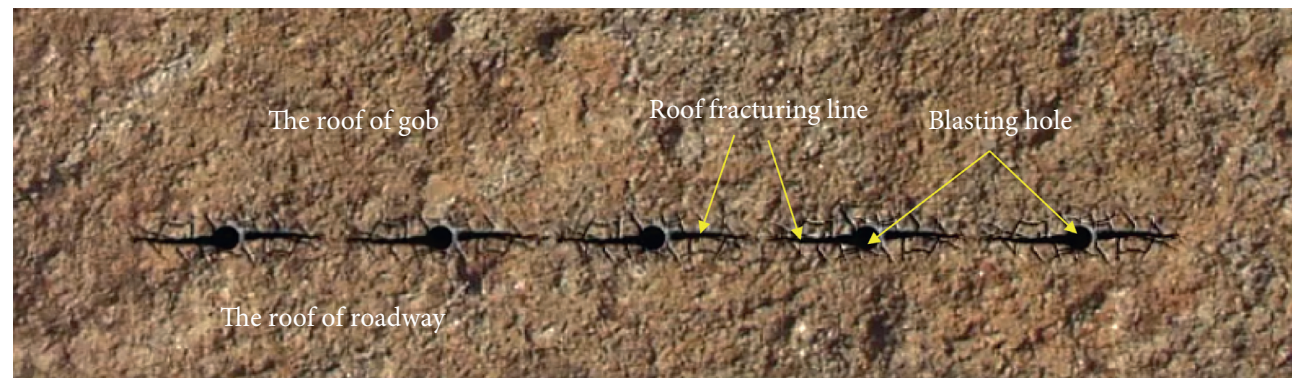

FIGURE 17: Fracture propagation due to blasting. 


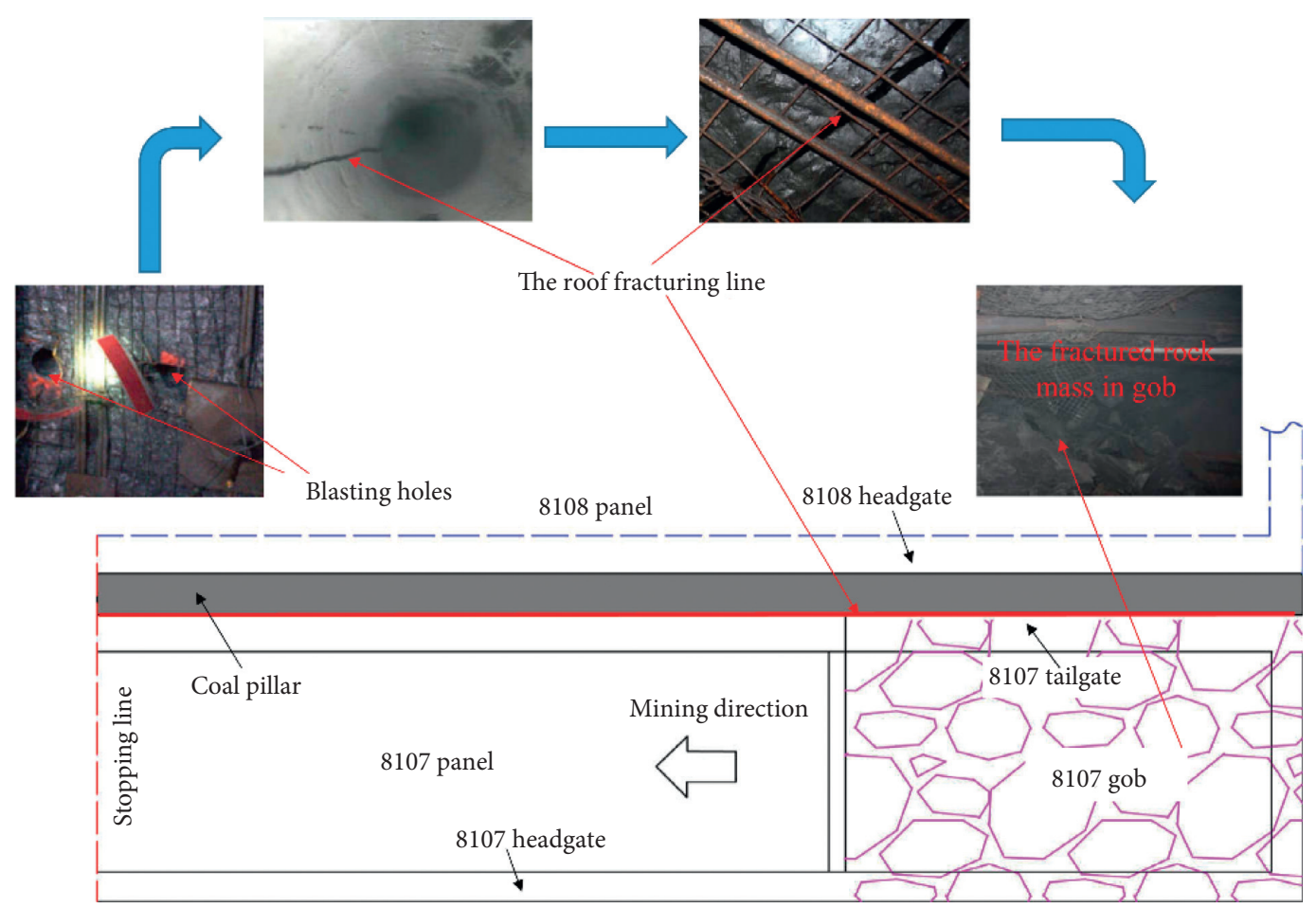

FIGURE 18: Exhibition of roof fracturing and rock mass filling.

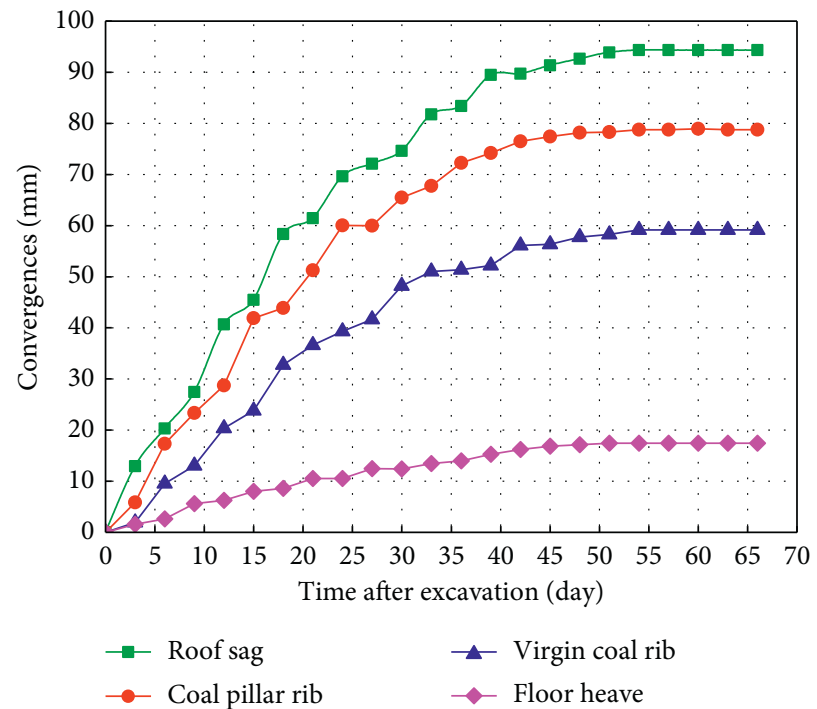

(a)

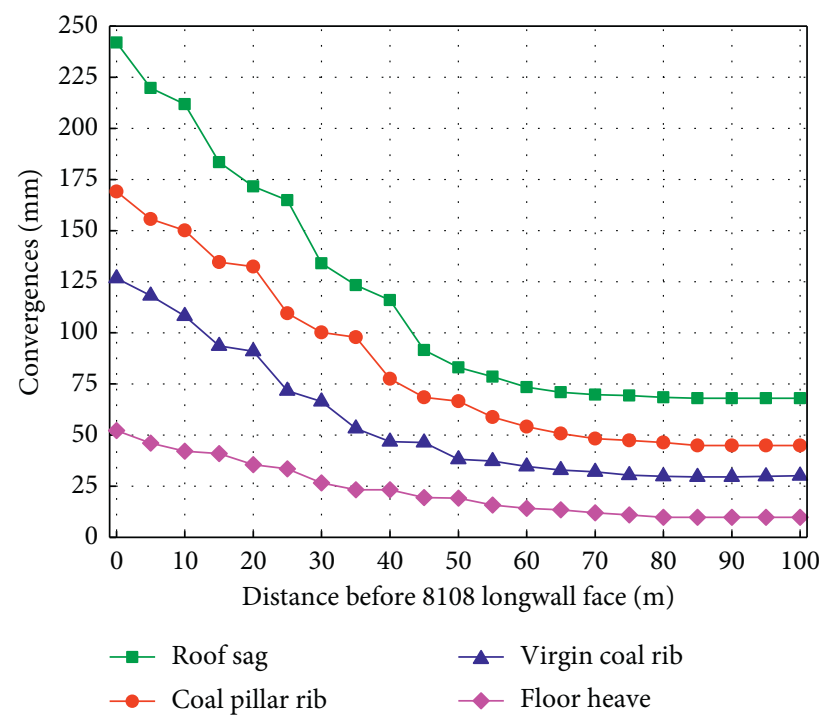

(b)

Figure 19: Measurement of 8108 headgate deformation. (a) During the 8108 headgate excavation. (b) During the 8108 panel retreat. 


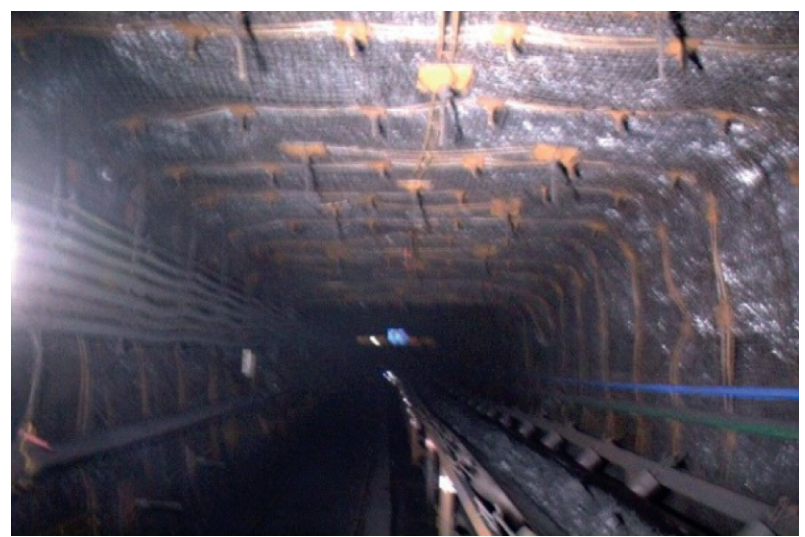

FIGURE 20: The stability of the 8108 headgate.

deformation was limited effectively by implementing the novel approach.

\section{Conclusions}

Based on the Wangzhuang coal mine in Shanxi Province, China, the failure mechanism and stability improvement process of a high-stress roadway were investigated through field tests and numerical simulations. A novel approach has been proposed for improving the stability of surrounding rock by roof fracturing and rock mass filling effect. This paper includes the following conclusions:

(1) A numerical model developed with UDEC software was adopted to analyse the fracture characteristics of the roof strata and the stress change in the roadway surrounding rock. By virtue of matching the synthetic rock specimen simulation results with the properties of the field rock mass, the microscopic parameters of the model blocks were obtained.

(2) The simulation results indicate that with roof fracturing, a stress distribution with two peaks existed in both ribs of the roadway due to the massive suspended roof, which kept the roadway in a state of high stress. Adopting the roof fracturing approach, the roof strata pressure carried by the two ribs in the roadway was reduced significantly. Additionally, because of broken rock bulking characteristics, the fractured rock mass in the gob provided better support on the upper strata, which effectively alleviated the coal pillar stress concentration and maintained a favourable stress environment around the roadway.

(3) A field test was implemented to control roadway deformation based on the roof fracturing and rock mass filling approach. The results demonstrated that the gob roof collapsed along the fracturing line and that the fractured rock mass in the gob contacted the overlying rock. Field data indicated that the stability of the 8108 headgate was greatly improved by employing this novel approach, providing an important reference for technical application and roadway excavation design in other coal mines with similar geological conditions.

\section{Data Availability}

The data used to support the findings of this study are included within the article.

\section{Conflicts of Interest}

The authors declare that they have no conflicts of interest.

\section{Acknowledgments}

This study was supported by the National Natural Science Foundation of China (no. 27183004).

\section{References}

[1] S.-Q. Yang, M. Chen, H.-W. Jing, K.-F. Chen, and B. Meng, “A case study on large deformation failure mechanism of deep soft rock roadway in Xin'An coal mine, China," Engineering Geology, vol. 217, pp. 89-101, 2017.

[2] J. B. Wei, S. M. Wang, Z. Zhao, and D. L. Li, "Numerical study of damage to rock surrounding an underground coal roadway excavation," Advances in Civil Engineering, vol. 2020, Article ID 8863289, , 2020.

[3] M. Fraldi and F. Guarracino, "Analytical solutions for collapse mechanisms in tunnels with arbitrary cross sections," International Journal of Solids and Structures, vol. 47, no. 2, pp. 216-223, 2010.

[4] S. Li, Q. Wang, B. Jiang et al., "Modeling and experimental study of mechanical properties of confined concrete arch in complicated deep underground engineering," Internal Journal of Geotechnics, vol. 17, no. 6, pp. 86-102, 2017.

[5] H. Kang, X. Zhang, L. Si, Y. Wu, and F. Gao, "In-situ stress measurements and stress distribution characteristics in underground coal mines in China," Engineering Geology, vol. 116, no. 3-4, pp. 333-345, 2010.

[6] B. Shen, A. King, and H. Guo, "Displacement, stress and seismicity in roadway roofs during mining-induced failure," International Journal of Rock Mechanics and Mining Sciences, vol. 45, no. 5, pp. 672-688, 2008.

[7] W.-L. Shen, J.-B. Bai, X.-Y. Wang, and Y. Yu, "Response and control technology for entry loaded by mining abutment stress of a thick hard roof," International Journal of Rock Mechanics and Mining Sciences, vol. 90, pp. 26-34, 2016.

[8] M. He, "Physical modeling of an underground roadway excavation in geologically $45^{\circ}$ inclined rock using infrared thermography," Engineering Geology, vol. 121, no. 3-4, pp. 165-176, 2011.

[9] S. C. Li, Q. Wang, H. T. Wang et al., "Model test study on surrounding rock deformation and failure mechanisms of deep roadways with thick top coal," Tunnelling and Underground Space Technology, vol. 47, pp. 52-63, 2015.

[10] X. Liu, H. Chen, K. Liu, and C. He, "Model test and stress distribution law of unsymmetrical loading tunnel in bedding rock mass," Arabian Journal of Geosciences, vol. 10, no. 7, pp. 184-192, 2017.

[11] X. Sun, F. Chen, C. Miao et al., "Physical modeling of deformation failure mechanism of surrounding rocks for the deep-buried tunnel in soft rock strata during the excavation," 
Tunnelling and Underground Space Technology, vol. 74, pp. 247-261, 2018.

[12] J. Coggan, F. Gao, D. Stead, and D. Elmo, "Numerical modelling of the effects of weak immediate roof lithology on coal mine roadway stability," International Journal of Coal Geology, vol. 90-91, pp. 100-109, 2012.

[13] Y. Kang, Q. Liu, and H. Xi, "Numerical analysis of THM coupling of a deeply buried roadway passing through composite strata and dense faults in a coal mine," Bulletin of Engineering Geology and the Environment, vol. 73, no. 1, pp. 77-86, 2014.

[14] B. Shen, "Coal mine roadway stability in soft rock: a case study," Rock Mechanics and Rock Engineering, vol. 47, no. 6, pp. 2225-2238, 2014.

[15] F. Gao, D. Stead, and H. Kang, "Numerical simulation of squeezing failure in a coal mine roadway due to mining-induced stresses," Rock Mechanics and Rock Engineering, vol. 48, no. 4, pp. 1635-1645, 2015.

[16] S.-L. Wang, S.-P. Hao, J.-B. Bai, X.-Y. Wang, and Y. Xu, "Numerical investigation of coal pillar failure under simultaneous static and dynamic loading," International Journal of Rock Mechanics and Mining Sciences, vol. 84, pp. 59-68, 2016.

[17] Z. Zhang, F. Chen, N. Li, G. Swoboda, and N. Liu, "Influence of fault on the surrounding rock stability of a tunnel: location and thickness," Tunnelling and Underground Space Technology, vol. 61, pp. 1-11, 2017.

[18] S. S. Peng, Longwall Mining, West Virginia University, Morgantown, MA, USA, 2006.

[19] D. N. Whittles, I. S. Lowndes, S. W. Kingman, C. Yates, and S. Jobling, "Influence of geotechnical factors on gas flow experienced in a UK longwall coal mine panel," International Journal of Rock Mechanics and Mining Sciences, vol. 43, no. 3, pp. 369-387, 2006.

[20] F. Z. Qi and Z. G. Ma, "Investigation of the roof presplitting and rock mass filling approach on controlling large deformations and coal bumps in deep high-stress roadways," Latin American Journal of Solids and Structures, vol. e190, pp. 1-24, 2019.

[21] UDEC, UDEC User Manual, Itasca Consulting Group, Minneapolis, MN, USA, 2008.

[22] L. Zhang and H. H. Einstein, "Using RQD to estimate the deformation modulus of rock masses," International Journal of Rock Mechanics and Mining Sciences, vol. 41, no. 2, pp. 337-341, 2004.

[23] M. Singh and K. Seshagiri Rao, "Empirical methods to estimate the strength of jointed rock masses," Engineering $\mathrm{Ge}$ ology, vol. 77, no. 1-2, pp. 127-137, 2005.

[24] S.-Q. Yang, M. Chen, G. Fang et al., "Physical experiment and numerical modelling of tunnel excavation in slanted uppersoft and lower-hard strata," Tunnelling and Underground Space Technology, vol. 82, pp. 248-264, 2018.

[25] S. Zhang, D. Zhang, H. Wang, and S. Liang, "Discrete element simulation of the control technology of large section roadway along a fault to drivage under strong mining," Journal of Geophysics and Engineering, vol. 15, no. 6, pp. 2642-2657, 2018.

[26] J. N. Liu, M. C. He, Y. J. Wang et al., "Stability analysis and monitoring method for the key block structure of the basic roof of noncoal pillar mining with automatically formed gobside entry," Advances in Civil Engineering, vol. 2019, Article ID 5347683, , 2019.

[27] Z. Cao and Y. Zhou, "Research on coal pillar width in roadway driving along goaf based on the stability of key block," CMC-
Computers Materials \& Continuation, vol. 48, no. 2, pp. 7790, 2015.

[28] S. Yan, J. Bai, X. Wang, and L. Huo, "An innovative approach for gateroad layout in highly gassy longwall top coal caving," International Journal of Rock Mechanics and Mining Sciences, vol. 59, pp. 33-41, 2013. 